\title{
Aromatase inhibitors for treatment of advanced breast cancer in postmenopausal women (Review)
}

\author{
Gibson L, Dawson C, Lawrence D, Bliss J
}

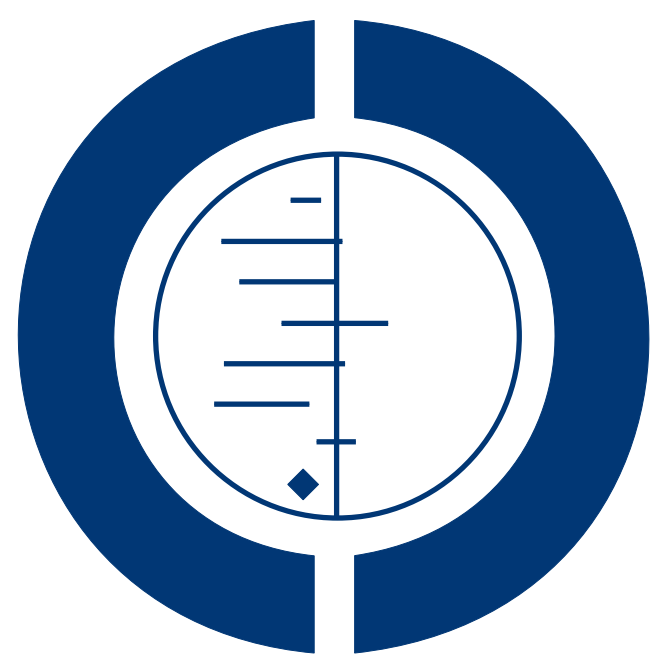

THE COCHRANE
COLLABORATION

This is a reprint of a Cochrane review, prepared and maintained by The Cochrane Collaboration and published in The Cochrane Library 2007, Issue 1

http://www.thecochranelibrary.com

\section{WILEY}

Aromatase inhibitors for treatment of advanced breast cancer in postmenopausal women (Review)

Copyright $\odot 2009$ The Cochrane Collaboration. Published by John Wiley \& Sons, Ltd. 
TABLE OF CONTENTS

HEADER . . . . . . . . . . . . . . . . . . . . . . . . . . . . . . . . . . . . . . . . 1

ABSTRACT . . . . . . . . . . . . . . . . . . . . . . . . . . . . . . . . . . . . . . . . . . . . . . .

PLAIN LANGUAGE SUMMARY . . . . . . . . . . . . . . . . . . . . . . . . . . . . . . . . . . . 2

BACKGROUND . . . . . . . . . . . . . . . . . . . . . . . . . . . . . . . . . . . . . .

OBJECTIVES . . . . . . . . . . . . . . . . . . . . . . . . . . . . . . . . . . . . . .

METHODS . . . . . . . . . . . . . . . . . . . . . . . . . . . . . . . . . . . . . .

RESULTS . . . . . . . . . . . . . . . . . . . . . . . . . . . . . . . . . . . . . . . 6

DISCUSSION . . . . . . . . . . . . . . . . . . . . . . . . . . . . . . . . . . . . . 11

AUTHORS' CONCLUSIONS . . . . . . . . . . . . . . . . . . . . . . . . . . . . . . . . . . . 12

ACKNOWLEDGEMENTS . . . . . . . . . . . . . . . . . . . . . . . . . . . . . . . . . 12

REFERENCES . . . . . . . . . . . . . . . . . . . . . . . . . . . . . . . . . . . . . . 12

CHARACTERISTICS OF STUDIES . . . . . . . . . . . . . . . . . . . . . . . . . . . . . . . . . . . . . . 17

DATA AND ANALYSES . . . . . . . . . . . . . . . . . . . . . . . . . . . . . . . . . . . . . . . . . . . 42 


\title{
[Intervention Review]
}

\section{Aromatase inhibitors for treatment of advanced breast cancer in postmenopausal women}

\author{
Lorna Gibson $^{2}$, Claire Dawson ${ }^{1}$, David Lawrence ${ }^{3}$, Judith Bliss ${ }^{1}$ \\ ${ }^{1}$ Clinical Trials and Statistics Unit, The Institute of Cancer Research, Sutton, UK. ${ }^{2}$ Cancer and Public Health Unit, London School \\ of Hygiene and Tropical Medicine, London, UK. ${ }^{3}$ Brent Teaching Primary Care Trust, Middlesex, UK \\ Contact address: Judith Bliss, Clinical Trials and Statistics Unit, The Institute of Cancer Research, 15 Cotswold Road, Sutton, Surrey, \\ UK. j.bliss@icr.ac.uk.
}

Editorial group: Cochrane Breast Cancer Group.

Publication status and date: Unchanged, published in Issue 3, 2009.

Review content assessed as up-to-date: 29 September 2005.

Citation: Gibson L, Dawson C, Lawrence D, Bliss J. Aromatase inhibitors for treatment of advanced breast cancer in postmenopausal women. Cochrane Database of Systematic Reviews 2007, Issue 1. Art. No.: CD003370. DOI: 10.1002/14651858.CD003370.pub2.

Copyright (C) 2009 The Cochrane Collaboration. Published by John Wiley \& Sons, Ltd.

\begin{abstract}
A B S T R A C T
Background

Hormonal treatments for advanced or metastatic breast cancer, such as tamoxifen and the progestins megestrol acetate and medroxyprogesterone acetate, have been in use for many years. Aromatase inhibitors (AIs) are a class of compounds that systemically inhibit oestrogen synthesis in the peripheral tissues. Aminoglutethimide was the first AI in clinical use (first generation) and had a similar tumour-regressing effect to other endocrine treatments, which showed the potential of this alternative type of therapy. Other AIs have since been developed and the third generation AIs anastrozole, exemestane and letrozole are in current use. Randomised evidence on response rates and side effects of these drugs is still limited.
\end{abstract}

Objectives

To compare aromatase inhibitors to other endocrine therapy in the treatment of advanced breast cancer in postmenopausal women.

\section{Search strategy}

The Cochrane Breast Cancer Group Specialised Register was first searched on 3 December 2004 using the codes for "advanced" and "endocrine therapy". Details of the search strategy applied to create the Register and the procedure used to code references are described in the Cochrane Breast Cancer Group module on The Cochrane Library. The search was updated to 30 September 2005 and additional publications were included. Experts were consulted to determine that no relevant studies had been excluded.

\section{Selection criteria}

Randomised trials comparing the effects of any aromatase inhibitor versus other endocrine therapy, no endocrine therapy or a different aromatase inhibitor in the treatment of advanced (metastatic) breast cancer.

\section{Data collection and analysis}

Data from published trials were extracted by two independent review authors. A third independent author then carried out a further cross check for accuracy and consistency. Hazard ratios (HR) were derived for analysis of time-to-event outcomes (overall and progressionfree). Odds ratios (OR) were derived for objective response and clinical benefit (both analysed as dichotomous variables). Toxicity data were extracted where present and treatments were compared using odds ratios. All but one of the studies included data on one or more of the following outcomes: overall survival, progression-free survival, clinical benefit and objective response.

Aromatase inhibitors for treatment of advanced breast cancer in postmenopausal women (Review)

Copyright $\odot 2009$ The Cochrane Collaboration. Published by John Wiley \& Sons, Ltd. 


\section{Main results}

Thirty studies were identified, twenty five of which were included in the main analysis of any AI versus any other treatment (9416 women). The pooled estimate showed a significant survival benefit for treatment with an AI over other endocrine therapies (HR 0.89, 95\% CI 0.82 to 0.96 ). A subgroup analysis of the three commonly prescribed AIs (anastrozole, exemestane, letrozole) also showed a similar survival benefit (HR 0.88, 95\%CI 0.80 to 0.96). The results for progression-free survival, clinical benefit and objective response were not statistically significant and there was statistically significant heterogeneity across types of AI. There were very limited data to compare one AI with a different AI, but these suggested an advantage for letrozole over anastrozole. All the trials of AIs used exclusively as first-line therapy were against tamoxifen. There was an advantage to treatment with AIs in terms of progression-free survival (HR $0.78,95 \%$ CI 0.70 to 0.86 ) and clinical benefit (OR $0.70,95 \%$ CI 0.51 to 0.97 ) but not overall survival or objective response. There was considerable heterogeneity across studies when considering clinical benefit $(\mathrm{P}=0.001)$. Use of an AI as second-line therapy showed a significant benefit in terms of overall survival (HR 0.80, 95\% CI 0.66 to 0.96 ) but not for progression-free survival (HR 1.08 , $95 \%$ CI 0.89 to 1.31 ), clinical benefit (OR $1.00,95 \%$ CI 0.87 to 1.14 ) or objective response (OR $0.96,95 \%$ CI 0.81 to 1.14 ). This is difficult to interpret due to the extreme heterogeneity across AIs for progression-free survival but not the other endpoints.

AIs have a different toxicity profile to other endocrine therapies. For all AIs combined, they had similar levels of hot flushes (especially when compared to tamoxifen) and arthralgia, increased risks of nausea, diarrhoea and vomiting, but a decreased risk of vaginal bleeding and thromboembolic events compared with other endocrine therapies. A similar pattern of risks and benefits was still seen when analyses were limited to the currently most-prescribed third generation AIs.

\section{Authors' conclusions}

In women with advanced (metastatic) breast cancer, aromatase inhibitors including those in current clinical use show a survival benefit when compared to other endocrine therapy.

\section{PLAIN LANGUAGESUMMARY}

\section{Aromatase inhibitors for treatment of advanced breast cancer in postmenopausal women}

Advanced (or metastatic) breast cancer is cancer that has spread beyond the breast. Endocrine therapy removes the influence of oestrogen on breast cancer cells and can prevent the cells from growing and spreading in early breast cancer if the tumour is hormone sensitive. Following a positive initial response to endocrine treatment, second and third line endocrine therapy is used until the disease becomes hormone resistant. This may extend a woman's life and improve her quality of life. Hormonal treatments for advanced breast cancer include tamoxifen, the progestins megestrol acetate and medroxyprogesterone acetate and aromatase inhibitors (AIs). AIs reduce the body's ability to make oestrogen (synthesis) and have tumour-regressing effects. The AIs in current clinical use include anastrozole, exemestane and letrozole.

The review authors identified 30 controlled studies in which over 10,000 women were randomised to treatment groups. Giving AIs improved survival (hazard ratio 0.9) but overall benefits on progression-free survival, clinical benefit and objective response were unclear. Studies using AIs as first-line and second-line therapy reported benefits of therapy that varied with the different AIs and measures of effectiveness. These agents have some different toxicity. AIs had similar levels of hot flushes and sweating (especially when compared to tamoxifen); increased risks of arthritic pain (arthralgia), rash, diarrhoea, nausea and vomiting; but decreased risk of vaginal bleeding and blood clotting (thromboembolic) events compared with other endocrine therapies.

\section{B A C K G R O U N D}

Breast cancer is the most common cause of cancer and cancer mortality in women worldwide (Ferlay 2000). Metastatic breast cancer occurs when the cancer has spread beyond the breast and regional node areas. Breast cancer can progress to metastatic disease despite a range of adjuvant systemic therapies. Once breast cancer is metastatic, it is no longer curable but it is treatable. The aim 
of any further treatment is to improve the individual's quality and length of life.

Endocrine therapy removes the influence of oestrogen on breast cancer cells, preventing the cancer cells from growing and spreading and has been shown to improve survival in early breast cancer. Early methods of therapy consisted of endocrine organ ablation by surgery (Beatson 1896) but these procedures have largely been superseded by effective hormonal treatments.

Most endocrine therapies either block the binding of oestrogen to its receptor or reduce serum and tumour concentrations of oestrogen. A positive initial response to endocrine treatment is a good indication for use of second and even third-line endocrine therapy until the disease becomes hormone resistant (Roseman 1997). The most important predictor of response to hormone therapy is the oestrogen receptor (ER) status of the original tumour.

Currently, the most widely-used endocrine therapy for treatment of hormone-sensitive metastatic disease is tamoxifen (Howell 1997). Tamoxifen is an oral, non-steroidal competitive ER antagonist. Tamoxifen, however, also has an agonist effect and although patients may relapse and develop acquired resistance to tamoxifen, this does not mean that they will not respond to other endocrine therapy.

Other endocrine therapies used in this setting are fulvestrant, megestrol acetate (MA) and medroxyprogesterone acetate (MPA). Fulvestrant is an ER antagonist that downregulates the ER and reduces progesterone receptor content but, unlike tamoxifen, does not have an agonist effect. It is used as a treatment for tamoxifenresistant advanced disease. MPA and MA are oral progestogens which have been shown to have significant antitumour activity after failure of other endocrine therapies in postmenopausal patients.

In postmenopausal women, oestrogen is no longer produced in the ovaries but androgens (mainly from the adrenal glands) are converted into oestrogens in peripheral tissue by the enzyme aromatase (Miller 1996a). Aromatase inhibitors (AIs) are a class of compounds that act systemically to inhibit oestrogen synthesis in tissues. AIs are of two types, reversible and irreversible; both types of inhibitors compete with normal substrates for binding on the enzyme. The non-competitive inhibitors (which are steroidal) leave the enzyme permanently inactivated (Ibrahim 1995).

AIs are classified as either first, second or third generation. Aminoglutethimide (AG) was the first AI and although effective it was poorly tolerated. This was supplanted by 4-hydroxy androstenedione (formestane) which was better tolerated. Third generation AIs fall into two principal categories (a) non-steroidal, reversible triazole derivatives (anastrozole, fadrozole, letrozole, vorozole ) and (b) steroidal, irreversible inhibitors (exemestane). The most widely used AIs are currently anastrozole, exemestane and letrozole.
AIs have a different toxicity profile to other endocrine therapies, although some that mimic menopausal symptoms due to depletion of oestrogen are the same, such as hot flushes and sweating. Adverse events particular to AIs include stomach upsets (nausea, vomiting, diarrhoea), rash and arthralgia. AG was poorly tolerated and can cause drowsiness, fever and inhibition of cortisol synthesis. Formestane, although generally well-tolerated as a treatment, resulted in local reaction around the injection site. Tamoxifen which was most widely used before AIs, can cause endometrial changes including vaginal bleeding and increased risk of thromboembolic events. Side effects with progestogens are usually mild but may may include hot flushes, night sweats, nausea and indigestion, fluid retention, weight gain and headaches as well as an increased risk of thromboembolism. Fulvestrant can have similar oestrogen deprivation side effects, injection site reactions, vomiting and diarrhoea.

AIs are now being used increasingly in the treatment of early breast cancer which may have an impact on their use in advanced (metastatic) disease.

\section{O B JE C T IVES}

The aim of this systematic review was to compare aromatase inhibitors to other endocrine therapy in the treatment of advanced (metastatic) breast cancer in postmenopausal women.

\section{METHODS}

\section{Criteria for considering studies for this review}

\section{Types of studies}

Only randomised controlled studies in the following populations were included:

- trials of patients with advanced (metastatic) breast cancer

- trials with results stratified by stage of disease so that it was possible to identify the subgroup of patients with advanced or metastatic breast cancer

\section{Types of participants}

Postmenopausal women with advanced or metastatic breast cancer either at diagnosis or upon relapse

- excluding those with local recurrence only;

- oestrogen receptor (ER) positive or status unknown;

- with no restrictions on metastatic site or age of the women;

- inclusion not limited to use of an AI as first-line therapy. 


\section{Types of interventions}

- Aromatase inhibitors versus any other endocrine treatment

- Aromatase inhibitors versus no endocrine treatment

- Aromatase inhibitors plus other endocrine treatment versus other endocrine treatment alone

- Direct comparison between different aromatase inhibitors

\section{Types of outcome measures}

Outcome measures were defined a priori as follows:

\section{Primary outcome}

Overall survival (defined as time from date of randomisation to date of death from any cause)

\section{Secondary outcomes}

1. Progression-free survival (defined as time from date of randomisation to disease progression), also known as time to progression 2. Clinical response rate. This comprises objective response (those women with either complete or partial shrinkage of the tumour) and clinical benefit (objective response plus stable disease for more than 24 weeks)*

3. Treatment toxicity (particularly AI related)

4. Quality of life (QOL), where available and comparable

5. Dropout rate

6. Time to treatment end (stopped or changed due to toxicity)

* International Union Against Cancer (UICC) guidelines for evaluation of these criteria (Hayward 1977).

\section{Subgroup analyses}

Performed where data were sufficient

- first-line therapy (where the AI was given as initial therapy for advanced disease);

- second-line therapy (where the advanced disease had already been treated with a different AI or another endocrine therapy);

- ER positive versus ER unknown;

- according to site of distant metastases and differential treatment effect.

\section{Search methods for identification of studies}

The Cochrane Breast Cancer Group Specialised Register was first searched on 3 December 2004 using the codes for "advanced" and "endocrine therapy". Details of the search strategy applied to create the Register and the procedure used to code references are described in the Cochrane Breast Cancer Group module on The Cochrane Library. The Cochrane Central Register of Controlled Trials (CENTRAL) and relevant conference proceedings were also searched. Reference sections of each published paper were searched for additional studies. The authors subsequently updated the search to 30 September 2005.

\section{Data collection and analysis}

\section{Assessing trials for eligibility \\ Study selection}

Trials identified through the search strategy were reviewed by two of the authors (CLD, LJG) who independently decided on eligibility; any differences were resolved by discussion and confirmed by a third author (DJL). Any exclusions have been justified and documented in the table Characteristics of excluded studies.

\section{Quality control and peer review}

Two authors (LJG and CLD) made an independent assessment of the quality of the trial based on the quality of the randomisation. For unpublished trials, information has been obtained from the protocol or other available source; however unpublished trials were not included in the review but are included in the ongoing trials. Where information was missing or additional information was required the authors were contacted but only two replies were received.

\section{Assessment of the methodological quality}

The quality of all studies deemed eligible was reviewed independently by two review authors (LJG, CLD) and discrepancies were resolved by discussion. The quality of each study was assessed based on reports in the publication on:

- quality of randomisation;

- comparability between the baseline characteristics of the treatment arms;

- inclusion of all randomised participants in the analysis;

- details of dropouts.

Randomisation was assessed by grading the allocation concealment (for example blinded, stratified) as $\mathrm{A}=$ adequate, $\mathrm{B}=$ unclear, $\mathrm{C}=$ inadequate (see Characteristics of included studies). It was not possible to assess the quality of randomisation accurately in all studies due to lack of information in the published articles. Any imbalance between treatment arms, both in numbers and characteristics, was taken into account in the grading.

Intention-to-treat statements: analyses that were stated to be by intention to treat included all randomised patients for the primary endpoint. However, it is common practice to report response variables, that is clinical benefit and objective response, only on 'assessable' patients. We have reported these outcomes on both assessable and randomised patients.

Description of the eligibility and exclusion criteria: all studies described in detail the patient characteristics of those patients eligible for the study. The table Characteristics of included studies includes information on the balance of baseline characteristics, details of patients excluded after randomisation, definitions of the outcome measures, duration of follow up and median length of follow up.

\section{Data extraction}

Data extraction was performed independently by two of the review authors (CLD, LJG) using data extraction forms designed for the purpose. Data extracted included details of treatment arms and patient numbers, baseline patient characteristics, tumour response 
rates, time to progression, median survival and median follow up. Data on toxicity and quality of life were extracted at a later date. The authors were not blinded to the source of the document for article selection or data extraction. A third author (DJL) assessed the data collected to ensure consistency and accuracy. Any differences were resolved by discussion. Data were extracted on quality as described in 'Assessment of the methodological quality'. Hazard ratios and their associated variances were extracted for all measures available. If a hazard ratio and confidence interval were not reported, these values were calculated (Parmar 1995). Of the report authors $(n=8)$ who were contacted for supplementary information on the primary endpoints, only two replied (and the data were not available).

\section{Analysis}

The most complete dataset feasible was assembled. Data were, however, only available for the following endpoints: overall survival, progression-free survival, clinical benefit, objective response and toxicity. The Cochrane Review Manager software (RevMan) was used to analyse the data. Statistical heterogeneity between studies was assessed using the chi-squared statistic.

Overall and progression-free survival were analysed using time-toevent methods and for this the hazard ratio (HR) is the most appropriate statistic. If a $\mathrm{HR}$ and corresponding confidence intervals (CI) were not reported, these values were calculated indirectly using median time to event (progression or survival) and the number of events extracted from the published Kaplan-Meier curves following the method of Parmar 1995. A weighted average of survival duration across studies was then calculated. A fixed effect model was used for the primary analyses (see the Cochrane Handbook for Systematic Reviews of Interventions) unless there was significant heterogeneity, in which case a random effects model was used. Ratios of treatment effects for time-to-event were reported so that HRs less than 1.0 favour the AI regimen.

Response rates were obtained from the tables of best response presented for each trial. Response has been analysed based on assessable (not randomised) patients as most of the trials included in this review only reported response in this way. As a sensitivity analysis, we also analysed results by intention to treat (ITT) and there was no difference. Response rates were analysed as dichotomous variables (for example objective response compared complete or partial response versus stable disease or no response). An odds ratio (OR) and its associated 95\% CI was calculated for each trial and a pooled OR derived. Ratios of treatment effects on response were reported so that ORs less than 1.0 favour the $\mathrm{AI}$ regimen.

Not all toxicities (also known as side effects or adverse events) were reported in this review. We selected six predefined toxicities from expert experience, reflecting side effects specific to AIs (nausea, diarrhoea, rash, arthralgia) and other hormonal treatments (hot flushes, vaginal bleeding, thromboembolic events). Each side effect was analysed as a dichotomous variable (yes or no) with the effect of the AI considered separately to that of the comparator. This was deemed the most informative method of presentation as the different comparators have different toxicity profiles whereas AIs have similar toxicity profiles. An OR and its associated 95\% CI were calculated for each trial and a pooled OR derived. Ratios of treatment effects for toxicity were reported so that ORs less than 1.0 favour the AI regimen.

Not all trials had data on toxicity and for those that did the data were not consistent among trials. Toxicity data were available for only 22 of the trials comparing an AI with a non-AI. Within studies, the reported toxicities varied both in the number or range and type of toxicities reported as well as the criteria used for reporting. Some studies reported predefined or selected toxicities (Bonneterre 2001; Kaufmann 2000; Mauriac 2003), some chose to report toxicities occurring in a certain minimum percentage of participants (Bezwoda 1998; Buzdar 2001; Dombernowsky 1998; Goss 1999; Mauriac 2003; Mourisden 2001), some used worst toxicity grades (Falkson 1996; Thuerlimann 1996; Thuerlimann 1997) or major toxicity (Canney 1988), one reported toxicity grades 1 to 4 separately (Paridaens 2003), one used common toxicities (Buzdar 1996a) though what this means was not defined, two reported adverse experiences (Buzdar 1996b; Buzdar 1996c) and one reported all toxicities (Rose 1986). Four studies did not state which reporting criteria they used. In addition, one study (Perez Carrion 1994) only reported on the toxicities considered to be treatmentrelated and has not been included. Despite the different reporting criteria the data were pooled so this must be borne in mind when looking at the absolute numbers.

\section{Quality of Life}

Eight studies quoted quality of life (QOL) as a secondary endpoint (Bezwoda 1998; Buzdar 1996b; Buzdar 1996c; Buzdar 2001; Goss 1999; Kaufmann 2000; Mauriac 2003; Thuerlimann 1997). One additional study (Dombernowsky 1998) mentioned that a QOL instrument was used at baseline and at each visit whilst on treatment but it was not mentioned as an endpoint nor were any data included. Three of the eight studies (Bezwoda 1998; Buzdar 1996b; Buzdar 1996c) did not report any QOL data. Only one (Thuerlimann 1997) has published two papers on the QOL data in detail.

There are several reasons why the limited QOL data are not included in this review: heterogeneous changes among patients, that is different symptoms and side effect profiles; different methods of drug application, that is injection versus tablets; use of four different QOL instruments at several different timepoints; some results given as responders versus non-responders rather than by treatment groups; some QOL measures based on clinician-reported rather than patient-reported symptoms.

\section{Dropout rates}

The number of actual dropouts was very difficult to quantify as the quantity and quality of reporting varied greatly. Numbers of patients were not given in six studies; numbers were not always 
given by treatment arm and only six studies gave full details. Three studies quoted the number of patients withdrawn due to toxicity as "a small number" (Buzdar 1996b; Buzdar 1996c; Kaufmann 2000). Thus the patients that could be confidently identified as lost to follow up, refusals or withdrawals totalled 51 .

\section{Time to treatment end}

No studies specifically stated time to treatment end. However, all but three of the studies (Leitzel 1995; Powles 1984; Tominaga 2003) reported on at least one of the following: time to progression, time to failure or time to death, or both of the latter.

Results are presented graphically and all figures follow the same format. Each trial is presented as a single line within each category. The point estimate of the treatment effect is represented by a square, the size of which is proportional to the size of the study. The associated $95 \% \mathrm{CI}$ is included as a horizontal line. The summary in each category is represented by a diamond, the north-south axis is the pooled estimate and the east-west axis is the $95 \% \mathrm{CI}$.

A pooled analysis was performed in each group, but the results from each aromatase inhibitor (AI) were considered separately within the same group, where possible. This approach is considered to be more informative due to differences between the AIs (first versus second versus third generation; steroidal versus nonsteroidal). Post hoc, it was decided also to present the pooled results for the AIs in current clinical use (by definition the newer, third generation AIs) separately as this is more relevant to the clinical situation today. The AIs included were: aminoglutethimide (first generation), formestane (second generation), anastrozole, exemestane, fadrozole, letrozole and vorozole (third generation). The nonAIs included are megestrol acetate (MA), tamoxifen, fulvestrant, medroxyprogesterone acetate (MPA) and hydrocortisone (HC). In all cases, tests for heterogeneity have been performed across all studies and in each of the treatment groupings outlined above. Instances of statistically significant heterogeneity will be discussed in the results section.

All analyses were based on the intention-to-treat principle (ITT) as far as possible, comparing all women allocated to one treatment versus all those allocated to the other, irrespective of compliance. Thus the result may slightly underestimate any treatment effects. However, analysis on response used the number of assessable women as the denominator, as this is the accepted method. As a sensitivity analysis, both denominators were used (see figures) and there was no major difference for response when comparing assessable to ITT. For statistical tests a P value of less than 0.05 was considered to denote statistical significance.

The Cochrane Review Manager Software (RevMan4) was used to analyse the data.

\section{R E S U L T S}

\section{Description of studies}

See: Characteristics of included studies; Characteristics of excluded studies; Characteristics of ongoing studies.

The search strategy yielded 152 English-language references, of which 133 were possibly eligible. Twenty five of the 133 references, relating to 22 trials were excluded as they compared the same AI at different doses. However, if a study compared two doses of an AI with a comparator the study was included using the arm with the standard dose of that particular AI versus the comparator. Other references were excluded because they were either non-English language papers, reviews, non-randomised studies or conference proceedings without the addition of published data. The exception to this the conference abstract by Schmid 2001 which is included as it presented several of the endpoints of this review in abstract form and there is no published paper of this study. From these, 50 relevant references were identified relating to 25 randomised trials which fulfilled the eligibility criteria. An additional five references for five studies were identified by the authors from reference lists in papers and reviews.

Thirty trials were included in this review and these trials randomised 11,208 women. There was a great deal of variation across studies. Trials ranged in size from 60 (Kleeberg 1997) to 1021 patients (Bonneterre 2001). Twelve studies randomised patients from multiple countries; of the remaining 18 studies, three were limited to the UK, two each from Spain and South America, and one from Canada, Denmark, Japan, Switzerland, and the US. The country was not reported in the remaining six studies.

Within the 30 trials, 9723 women were randomised in 26 trials comparing AIs with non-AIs, and 1485 women were randomised in four trials of one AI versus a different AI. It should be noted that seven studies included two different doses of an AI compared with a third comparison. The decision was made to include only data from the arm of the study which included the most commonly used dose of the AI. For anastrozole this was $1 \mathrm{mg}$ and for fadrozole $2.5 \mathrm{mg}$, or $2 \mathrm{mg}$ if $2.5 \mathrm{mg}$ was not used. The number of included randomised women for all 30 studies was 10,054.

Of the 26 trials comparing AIs with non-AIs, seven used the first generation $\mathrm{AI}$ aminogluthetimide, two used the second generation AI formestane, and 17 used a third generation AI (anastrozole, four trials; exemestane, two; fadrozole, six; letrozole, four; vorozole, one). In these studies the comparator was tamoxifen in 11 trials, MA in 12, MPA in one, hydrocortisone (HC) in one and fulvestrant in one.

The four trials of AIs versus a different AI compared letrozole versus aminoglutethimide and anastrozole, fadrozole, exemestane or anastrozole versus formestane.

In 10 of the 30 studies (randomising 3635 women), any AI was used as first-line treatment versus any other comparator, which was tamoxifen in all of them. In 14 of 30 studies (5349 randomised women) any AI was compared with any comparator as secondline therapy. In the remaining seven trials the AIs were used as both first and second-line treatments within the trials but as the

Aromatase inhibitors for treatment of advanced breast cancer in postmenopausal women (Review) 
data were not split by this variable they were not included in these comparisons.

Data for all endpoints were not available in the published reports. Thus five principal endpoints with sufficient data were identified: overall survival, progression-free survival, response (either based on clinical benefit or objective response) and treatment toxicity. These principal endpoints were not available from all papers. Where data were unavailable, authors were approached for supplementary data.

Data were not available in the published reports for all groups outlined in the review protocol. The most data were available for the AI versus any non-AI group and therefore results for all five endpoints were presented as well as a subgroup consisting of data from the three most commonly prescribed AIs, that is anastrozole, exemestane and letrozole. In addition, the results of four of the five endpoints (not toxicity) outlined above are presented in three separate groups based on: individual AIs versus different AIs, AIs used as first-line treatment only, AIs used as second-line therapy only.

\section{Risk of bias in included studies}

Thirty randomised studies were included in this review. Non-randomised studies were excluded at the selection stage as they did not fulfil the inclusion criteria. One of the included studies did not have data on the primary or secondary endpoints so could not be included in any analysis. It should be noted that trials by the author of one of the included studies Bezwoda 1998, relating to high dose chemotherapy, have been found to include falsified data. However, no such findings have been reported for trials included in this review and there was therefore no reason to exclude this study. Analysis was performed with and without this study and there was no difference in the pooled results, although for clinical benefit the result became just significant.

It was not possible to assess the quality of all studies accurately due to lack of information, including the quality of the randomisation process, in the published articles. Randomisation was rated as adequate in 18 studies but there were insufficient details of the randomisation process in the remaining 12 and so they were labelled as unclear. Of these, no randomisation method was given in six studies and four were reported to have parallel groups. No studies were deemed to have inadequate randomisation from the information given in the published papers and none were excluded for this reason.

Baseline characteristics were not commented upon in 10 studies, five studies commented on a slight imbalance. One study (Buzdar 1996a) had an imbalance in the treatment arm but this was believed to be an artefact. All other studies reported balanced baseline characteristics in all arms.

The AI arm in some of the older studies (Alonso-Munoz 1988; Canney 1988; Ingle 1986; Powles 1984; Rose 1986; Russell 1997) did not compare an AI by itself but in combination with another treatment.

\section{Summary of numbers of women used in the analysis \\ Women randomised, all arms $=11,208$ \\ Women randomised, included arms $=10,054$ \\ Women randomised, assessable (for response) $=8842$}

\section{Effects of interventions}

Over 10,000 women were randomised to the included arms of 30 trials, but time-to-event data was only available for about half of them. The results of the meta-analysis should be interpreted bearing this in mind.

Aromatase inhibitors versus any non-aromatase inhibitor Of the 26 trials comparing an AI versus a non-AI one had no data on response or survival by treatment arm although these were included as endpoints (Leitzel 1995). Of the remaining 25 trials, data were available on overall tumour response rates data in all 25 , clinical benefit in 22, progression-free survival in 10 and overall survival in 12 trials. For overall survival, the reported figures were available from the publications for six trials (Bonneterre 2001; Buzdar 1996a; Buzdar 2001; Ingle 1986; Dombernowsky 1998; Thuerlimann 1996 ) and were calculated for six trials (Bezwoda 1998; Goss 1999; Kaufmann 2000; Milla-Santos 2003; Rose 1986; Russell 1997). In terms of progression-free survival, HRs were reported in the publications of four trials (Bonneterre 2001; Buzdar 2001; Ingle 1986; Mourisden 2001). The remaining six trials (Dombernowsky 1998; Goss 1999; Kaufmann 2000; Mauriac 2003; Russell 1997; Thuerlimann 1997) had sufficient data for calculation of the HRs.

\section{Overall survival}

Data on survival were available in 12 trials reporting an estimated 2576 events in 4548 women. No data were available for formestane. The pooled HR of 0.89 (95\% CI 0.82 to 0.96$)$ shows a statistically significant $11 \%$ benefit of treatment $(P=0.003)$ with an AI, with a consistent effect across all subgroups. Data on individual AIs were sparse and no conclusions could be drawn.

\section{Progression-free survival}

Data on progression were available in 10 trials reporting an estimated 3791 events in 5355 women. Progression was not statically significantly associated with the use of an AI (HR 0.97, 95\% CI 0.83 to 1.14 ). This overall effect is virtually uninterpretable due to the significant heterogeneity by type of $\mathrm{AI}$ and also within specific AIs. Exemestane was statistically significantly better than the non-AI whereas vorozole was significantly worse. The exemestane results are based on a single study. The pooled HRs for both anastrozole (Bonneterre 2001; Mauriac 2003) and letrozole (Buzdar 2001; Dombernowsky 1998; Mourisden 2001) were not statistically significant with highly significant heterogeneity across the studies $(\mathrm{P}<0.00001$ and $\mathrm{P}=0.01$, respectively). 


\section{Proportion of women with clinical benefit (7594 assessable women)}

Data were available for seven AIs (aminoglutethimide, formestane, anastrozole, exemestane, fadrozole, letrozole, vorozole) from 22 trials. Approximately one quarter of the data came from two studies (Bonneterre 2001; Mourisden 2001). The AIs were not shown to be superior to the non-AIs $(\mathrm{P}=0.09)$ and there was statistically significant heterogeneity $(\mathrm{P}=0.004)$ across studies.

\section{Proportion of women with objective response (7919 assess- able women)}

Twenty five trials reported objective response. Data were available for seven AIs (aminoglutethimide, formestane, anastrozole, exemestane, fadrozole, letrozole, vorozole). The pooled OR suggested no statistically significant effect of treatment with an AI (P $=0.09)$ and again there was statistically significant heterogeneity $(\mathrm{P}=0.02)$. Of the individual AIs, only letrozole was associated with a statistically significant benefit over the non-AI (OR 0.65, $95 \%$ CI 0.51 to 0.82 ) in 1637 women randomised (Buzdar 2001; Dombernowsky 1998; Mourisden 2001; Schmid 2001).

\section{Toxicity}

Not all trials had data on toxicity and for those that did the data were not consistent among all trials. Toxicity data were available for only 22 of the trials comparing an AI with a non-AI. Within studies, the reported toxicities varied both in the number or range and type of toxicities reported as well as the criteria used for reporting. Some studies reported predefined or selected toxicities (Bonneterre 2001; Kaufmann 2000; Mauriac 2003) some chose to report toxicities occurring in a minimum percentage of participants (Bezwoda 1998; Buzdar 2001; Dombernowsky 1998; Goss 1999; Mauriac 2003; Mourisden 2001), some used worst toxicity grade (Falkson 1996; Thuerlimann 1996; Thuerlimann 1997) or major toxicity (Canney 1988), one reported toxicity grades 1 - 4 separately (Paridaens 2003), one used common toxicities (Buzdar 1996a) though what this means is not defined, two reported adverse experiences (Buzdar 1996b; Buzdar 1996c) and one reported all toxicities (Rose 1986). Four studies did not state which reporting criteria they used. For the study of an AI against fulvestrant (Mauriac 2003), data on toxicity were obtained from different sources. The combined analysis of the two trials 0020 and 0021 reported predefined events and data on hot flushes and thromboembolic events were available. The separate publications of the results of 0020 and 0021 detailed toxicities occurring in $10 \%$ or more of the participants. Trial 0020 reported data on both nausea and vomiting so these were combined with these data from 0021 . In addition, trial 0021 had data on the frequency of diarrhoea and rash. Four studies did not state which reporting criteria they used. One study (Perez Carrion 1994) only reported on the toxicities considered to be treatment-related and has not been included. Despite these reporting differences, data from all trials were pooled as otherwise there would have been too few data for each comparator and symptom. The analyses have been split according to the comparator due to the different toxicity profiles of each com- parator and so the pooled results have not been reported. Hot flushes

Hot flushes was the specific toxicity that was most widely reported. Data on hot flushes were available from 18 studies with 7059 women. Of these, seven compared an AI with tamoxifen, nine with MA and one each with fulvestrant and MPA. The use of an AI had very similar risk of hot flushes to tamoxifen and fulvestrant. The AI was associated with statistically signficantly more reports of hot flushes than with MA (OR 1.77, 95\% CI 1.42 to 2.20 ) but less than with MPA (OR 0.20, 95\% CI 0.06 to 0.73 ) which had data from only one trial.

Nausea

Data on nausea were available from 15 studies with 6602 women. Another two trials reported data on nausea and vomiting combined. Of the 15, six compared an AI with tamoxifen, eight with $\mathrm{MA}$ and one with fulvestrant. AIs were associated with a statistically significant increase in risk of nausea compared to MA (OR $1.84,95 \%$ CI 1.37 to 2.47 ) but there was no statistically significant difference between AIs and tamoxifen $(\mathrm{P}=0.32)$ or fulvestrant $(\mathrm{P}=0.81)$.

Vomiting

Two studies had data on nausea and vomiting combined and so were not included. Data on vomiting were available from two studies comparing AIs with tamoxifen, five versus MA and one versus fulvestrant for a total of 4404 women. The AI was statistically significantly worse when compared to MA (OR 2.03, 95\% CI 1.42 to 2.90). The comparisons with tamoxifen and fulvestrant suggested no statistically significant differences.

Diarrhoea

Nine studies with 4507 women had data on diarrhoea toxicity. Of these, three compared an AI with tamoxifen, five with MA and one with fulvestrant. AIs were associated with a statistically significant higher rate of diarrhoea than either tamoxifen (OR 1.64, 95\% CI 1.06 to 2.55 ) or MA (OR 1.48, 95\% CI 1.02 to 2.13) but not fulvestrant $(\mathrm{P}=0.19)$.

\section{Rash}

Twelve studies with 3822 women had data on rash toxicity. Of these, four compared an AI with tamoxifen, six with MA, and one each with MPA and fulvestrant. AIs were associated with a statistically significant increased risk of rash when compared with tamoxifen (OR 33.61, 95\% CI 4.71 to 239.97) and for the one trial versus MPA (OR 111.71, 95\% CI 6.75 to 1849.91 ) but not against MA or fulvestrant. Within the comparison with MA there was statistically significant heterogeneity $(P=0.0005)$.

\section{Vaginal bleeding}

Data on vaginal bleeding were reported in four studies of 2150 women, two compared an AI with MA and one each with tamoxifen and MPA. Compared with MA, there was a statistically significant benefit of $71 \%$ to treatment with the AI (OR 0.29, 95\% CI 0.13 to 0.65 ). The one trial versus MPA also found a statistically 
significant difference with an OR of 0.10 ( $95 \%$ CI 0.01 to 0.77 ). There was no statistically significant difference between AIs and tamoxifen $(\mathrm{P}=0.15)$..

\section{Thromboembolic events}

Thromboembolic event data were available from six studies with 2937 women. Two compared an AI with tamoxifen, three with MA and one with fulvestrant. The AI had a statistically significant advantage over tamoxifen (OR $0.48,95 \%$ CI 0.27 to 0.85 ) only.

\section{Arthralgia}

Data on arthralgia were available for 2470 women in two studies versus tamoxifen $(\mathrm{N}=1031)$ and four studies versus MA $(\mathrm{N}=$ 1439). There was no statistically significant difference between the AIs and either tamoxifen or MA.

\section{Subgroup analysis: aromatase inhibitors in current clinical use versus any non-aromatase inhibitor \\ Ten of the 25 trials comparing an AI with a non-AI were on the three AIs in current clinical use, namely anastrozole, exemestane and letrozole. The pooled results for these are reported. Data on overall survival and time to progression were available from only six trials but response rates and clinical benefit were available from all 10. In terms of survival, HRs were reported in the publications of four trials (anastrozole (Bonneterre 2001; Buzdar 1996a) and letrozole ( Buzdar 2001; Dombernowsky 1998). Another two tri- als (Kaufmann 2000; Milla-Santos 2003) had sufficient data for calculation of the HRs. For time to progression, the correspond- ing number of trials were three (Bonneterre 2001; Buzdar 2001; Mourisden 2001) and three (Dombernowsky 1998; Kaufmann 2000; Mauriac 2003), respectively.}

\section{Overall survival}

Data on survival were available from six trials (Bonneterre 2001; Buzdar 1996a; Buzdar 2001; Dombernowsky 1998; Kaufmann 2000; Milla-Santos 2003). The AI was statistically significantly superior to the non-AI with a HR of 0.88 (95\% CI 0.80 to 0.96 ), equivalent to a $12 \%$ benefit of treatment with an AI. This effect was consistent across all subgroups.

\section{Progression-free survival}

Data on progression were available from six trials (Bonneterre 2001; Buzdar 2001; Dombernowsky 1998; Kaufmann 2000; Mauriac 2003; Mourisden 2001) reporting an estimated 3060 events in 4333 women. Use of an AI was not statistically significantly associated with a change in the hazard of progression (HR $0.92,95 \%$ CI $0.75-1.13)$. The results varied by type of AI with only exemestane (one trial only) being statistically significantly better than the non-AI and there was no evidence of an effect for anastrozole. There was significant heterogeneity both in the pooled result $(\mathrm{P}<0.00001)$ and within the anastrozole trials $(\mathrm{P}<0.00001)$. 3. Proportion of women with clinical benefit (5079 assessable women)

Data were available from 10 trials. The pooled OR suggested a statistically significant advantage to the AI of $22 \%$ (OR 0.78, 95\%
CI 0.63 to 0.96 ). There was statistically significant heterogeneity among the trials $(\mathrm{P}=0.002)$.

\section{Proportion of women with objective response (5079 assess- able women)}

All 10 trials reported objective response. The pooled OR of 0.77 (95\% CI 0.62 to 0.96 ) showed a statistically significant advantage to the AI but there was statistically significant heterogeneity ( $\mathrm{P}$ $=0.03)$ across the trial results. There was also significant heterogeneity within the exemestane trials.

\section{Toxicity}

One of the suggested benefits of the third generation AIs is a reduced toxicity profile. Therefore toxicity data were extracted for the three most commonly used AIs at this time, that is anastrozole, exemestane and letrozole. The results were presented by comparator as the comparators have different toxicity profiles whereas the AIs have similar toxicity profiles. The denominators for the comparison of anastrozole with fulvestrant vary depending on whether the combined trial results were available (hot flushes, nausea, vomiting, thromboembolic events) or not (diarrhoea, rash).

\section{Hot flushes}

Hot flushes was the specific toxicity that was reported most widely. Data on hot flushes were available from eight of the 10 studies, with 4930 women. Three studies compared the AI with tamoxifen, four with MA and one with fulvestrant. The use of an AI had a very similar risk of hot flushes to tamoxifen and fulvestrant but was associated with statistically significant more reports of hot flushes than with MA (OR 1.69 , 95\% CI 1.24 to 2.30 ).

\section{Nausea}

Data on nausea were available from eight of the 10 studies, with 4930 women. Of the eight studies, three compared an AI with tamoxifen, four with MA and one with fulvestrant. The AIs had statistically signicantly more reports of nausea than MA (OR 1.45, $95 \%$ CI 1.09 to 1.95 ) but there was no statistically significant difference when the AIs were compared to tamoxifen or fulvestrant. Vomiting

Five studies with 3499 women had data on vomiting alone and only one made the comparison with tamoxifen. There was no statistically significant differences between the AI and either tamoxifen or fulvestrant. Compared with MA, the AIs had a statistically significantly increased risk of vomiting (OR 1.77, 95\% CI 1.11 to 2.83).

Diarrhoea

Six studies with 3602 women had data on diarrhoea toxicity. Two compared an AI with tamoxifen, three with MA and one with fulvestrant. There was a statistically significant increased risk of diarrhoea with the AIs against MA (OR 2.40, 95\% CI 1.34 to 4.29).

Rash

Four studies with 2033 women comparing AIs with MA or ful- 
vestrant had data on rash. AIs were not associated with a statistically significant increased risk of rash and there was statistically significant heterogeneity among the three studies with MA as the comparator $(\mathrm{P}=0.04)$.

\section{Vaginal bleeding}

Data on vaginal bleeding were reported in three studies with 1932 women, one compared an AI with tamoxifen and two with MA. There was a statistically significant benefit to treatment with the AIs in comparison with MA (OR $0.29,95 \%$ CI 0.13 to 0.65 ).

Thromboembolic events

Thromboembolic event data were available for 2378 women in three studies but there was only one study per comparator (tamoxifen, MA or fulvestrant). AIs were associated with a statistically significantly lower incidence of thromboembolic events than tamoxifen (OR 0.53 , 95\% CI 0.29 to 0.96 ) but not compared with MA or fulvestrant.

Arthralgia

Data on arthralgia as a specific side effect were only available for 1394 women in three studies, two versus tamoxifen and one versus MA. Against both comparators, the AI was not statistically significantly associated with a difference in the incidence of arthralgia. Other analyses

\section{Aromatase inhibitors versus any different aromatase inhibitor A total of 1481 women in four trials were randomised to one AI versus a different AI. Of these, all four had data on response but only one had results on overall survival and progression-free sur- vival (Gershanovich 1998). Letrozole was compared with a differ- ent AI in all the trials (Gershanovich 1998, Rose 2003, Tominaga 2003) except that of Kleeberg 1997 which compared anastrozole with formestane. The study by Rose and colleagues (Rose 2003) compared letrozole to anastrozole and in this section has been in- cluded in both the letrozole and anastrozole groups.}

\section{Overall survival}

The Gershanovich 1998 study cited above was the only one in this section that had data on overall survival. Letrozole had a statistically significant reduced HR of 0.64 (95\% CI 0.49 to 0.84$)$ giving a $36 \%$ advantage in survival over aminoglutethimide treatment.

\section{Progression-free survival}

Only one study had data on progression from 551 women (Gershanovich 1998). In this study, letrozole was associated with a reduced hazard (HR 0.72 , 95\% CI 0.57 to 0.91 ) showing a $28 \%$ advantage in terms of progression-free survival compared to aminoglutethimide.

\section{Proportion of assessable women with clinical benefit (1152 assessable patients)}

Data were available from 1152 assessable women. Letrozole was statistically significantly associated with a statistically significant clinical benefit compared with a different AI (OR 0.72, 95\% CI 0.56 to 0.93 ). There was no significant study heterogeneity, $\mathrm{P}=$
0.57 .

4. Proportion of assessable women with objective response (1152 assessable patients)

Data were available from 1152 assessable women. The pooled overall result is not presented as Rose 2003 was included in both individual AI comparisons and so would be counted twice. Letrozole was statistically significantly different from any other AI (OR $0.53,95 \%$ CI 0.39 - 0.73). Results of all letrozole studies are consistent (test for heterogeneity $\mathrm{P}=0.45$ ). Anastrozole appeared to be significantly inferior to a different AI (OR 1.59, 95\% CI 1.07 to 2.37$)$.

Aromatase inhibition as first-line therapy versus any other therapy (tamoxifen)

Ten studies that randomised 3635 women used AIs exclusively as first-line therapy for advanced (metastatic) disease and all comparisons were against tamoxifen. We did not include any studies that were mixed first and second-line. Data from two studies with 1242 women (anastrozole and fadrozole) were available for overall survival and three studies with 2139 women (one study each on formestane, anastrozole, and letrozole) for progressionfree survival. All 10 studies reported results for objective response and eight studies for clinical benefit.

\section{Overall survival}

Data were only available from two studies with 1242 women, one each on anastrozole and fadrozole. There was no statistically significant difference in the effect of treatment with an AI compared to tamoxifen.

\section{Progression-free survival}

Data were available from three of the 10 studies. The first-line AI regimen was statistically significantly superior to tamoxifen with a decreased hazard of 0.78 (95\% CI 0.70 to 0.86). Anastrozole (Bonneterre 2001) and letrozole (Mourisden 2001) were statistically significantly different from tamoxifen (reduced hazard of $18 \%$ and $30 \%$, respectively).

\section{Clinical benefit (3036 assessable women)}

Data on clinical benefit were available from 3036 assessable women. As results for individual AIs, except for aminoglutethimide and anastrozole, were based on only a single study the pooled result is emphasised. The AIs were significantly better than tamoxifen as first-line therapy (OR $0.70,95 \%$ CI 0.51 to 0.97 ) but there was significant heterogeneity across the AIs ( $\mathrm{P}=$ 0.001 ). The individual results for exemestane and letrozole were statistically significant in the analysis of assessable women but for letrozole only based on the analysis of randomised women.

\section{Proportion of assessable women with objective response (3287 assessable women)}

Data on objective response were available from 3287 assessable women. Aminoglutethimide was the only AI with more than two studies published. The AIs were not statistically significantly bet- 
ter than tamoxifen as first-line therapy. There was considerable heterogeneity $(\mathrm{P}=0.006)$ by type of AI. Exemestane and letrozole were the only AIs that were statistically significantly better than tamoxifen but in both cases the results are only based on one study. The other AIs appear to have little impact on objective response.

\section{Aromatase inhibition as second-line therapy versus any other therapy}

Women who had previously been treated with endocrine therapy, either a different $\mathrm{AI}$ or non-AI, for advanced (metastatic) disease and received the study AI as second-line therapy were included in 14 trials. Aminoglutethimide was used as second-line in three studies, formestane in one, anastrozole in two, exemestane in one, fadrozole in three, letrozole in two and vorozole in one. The majority of the comparisons (10) were against MA. One trial (Rose 2003) which compared anastrozole to letrozole was not included in the analysis. We did not include trials where there was a mixture of first and second-line therapy.

Data on objective response were available from all of the trials, clinical benefit from 11 trials, HRs for progression-free survival from six trials and HRs for overall survival from two trials.

\section{Overall survival}

Data on overall survival were limited, with data from two trials of different AIs, anastrozole and letrozole. Second line treatment with an AI was statistically significantly associated with a decreased hazard of death (HR 0.80, 95\% CI 0.66 to 0.96). This effect was consistent for both AIs (heterogeneity $\mathrm{P}=0.79$ ).

\section{Progression-free survival}

AI use was not associated with a statistically significant difference in the risk of progression. There was significant heterogeneity (P $=0.0002$ ) across studies with use of either anastrozole or vorozole associated with a significantly increased risk of progression and exemestane associated with a statistically significant decrease.

\section{Proportion of assessable women with clinical benefit (3721 assessable women)}

There did not appear to be any effect in terms of a statistically significant clinical benefit when an AI was used as second-line therapy. This lack of effect was consistent across AI subgroups (heterogeneity $\mathrm{P}=0.95$ ).

\section{Proportion of assessable women with objective response (4170 assessable women)}

Overall there was no statistically significant difference between the use of an AI as second-line therapy and any other therapy. When looking at individual AIs none showed any evidence of a benefit, but this was based on small numbers. There was no statistical heterogeneity $(\mathrm{P}=0.33)$.

\section{DISCUSSIO N}

This review demonstrates that there is a survival benefit of $11 \%$ from using AIs for the treatment of advanced (metastatic) breast cancer. This finding is not consistent across all AIs, with the greatest benefit associated with the AIs in current clinical use, namely anastrozole, exemestane and letrozole. However, data on survival were only available for about half of the women and one of the trials (Buzdar 1996a) was not designed or powered to detect significant differences in survival.

The positive effects of AIs in terms of tumour response when given as first or second-line therapy were statistically significant for firstline therapy where the comparator was tamoxifen. There were no data available on other comparators. When comparing the effect of the AI as second-line therapy there was no statistically significant difference when considering tumour response. In terms of progression-free survival, there was a statistically significant decreased hazard of progression for treatment with the AIs as first line-therapy only. The paucity of data makes it difficult to make any firm conclusions in terms of overall survival.

In terms of toxicity, AIs are known to be associated with a higher incidence of nausea, diarrhoea, rash and arthralgia but a lower risk of vaginal bleeding and thromboembolic events. There was a higher incidence of hot flushes with AIs when compared to MA but not when compared to tamoxifen. However, combining data across studies was difficult as both the toxicities reported and the criteria for reporting toxicities, if they were reported at all, varied greatly.

This review has combined data from a wide variety of studies that were carried out over 20 years. Some of the trials did not use an AI as a single agent but in combination with another endocrine therapy. There was heterogeneity both across types of AI and within each AI. The results of studies of three generations of AIs have been combined as well as results from studies of steroidal and nonsteroidal therapy. This has been forced to some extent by the lack of data on individual AIs.

Evidence of heterogeneity between trials was identified for tumour response rates and progression-free survival though not overall survival. The reasons for this are unknown but this statistical heterogeneity may be explained by clinical heterogeneity. It may be that outcomes involving subjective endpoints, that is tumour response, may be subject to variation whereas the hard endpoint used in the survival analysis is unequivocal. Other contributory factors may be the difference in dosage of some AIs and significant differences in the proportion of patients who were truly hormone receptor positive.

Within each AI, studies varied in terms of sample size, dose of AI, comparison regimen, outcomes, length of follow up and quality of reporting. For example, the seven studies of aminoglutethimide consisted of between 62 and 313 patients; three of the studies were of first-line therapy, three second-line and one mixed. Doses of aminoglutethimide used were $125 \mathrm{mg}$ in one study, $250 \mathrm{mg}^{*}$ in 
one, $500 \mathrm{mg}^{*}$ in three, $750 \mathrm{mg}$ in one and $1000 \mathrm{mg}$ in one (* dose doubled after a specific period of treatment). The comparator was tamoxifen in four studies $(20 \mathrm{mg}$ in two, $30 \mathrm{mg}$ in one, $40 \mathrm{mg}$ in one), MA $160 \mathrm{mg}$ in one, MPA $1000 \mathrm{mg}$ in one and HC $20 \mathrm{mg}$ in one. Not all endpoints were available in each study: three reported overall survival, two progression-free survival, five clinical benefit and seven objective response.

There are very limited data on quality of life reported in this setting. The limited quality of life data which was reported did not show any significant differences between the AI and comparator groups, however some differences were found with some subscales in favour of the AI (Goss 1999; Kaufmann 2000). The patient's perspective in advanced disease treatment is an important endpoint and should be included in studies as it would aid interpretation in this mainly palliative setting.

A lack of standardised reporting of clinical endpoints impacted upon the analysis of all AIs, not just aminoglutethimide. Therefore, it was not possible to include all studies in each section, which impacted on the power of certain analyses, especially overall and progression-free survival. In addition, many of the data required to carry out analyses of prospectively identified subgroups, as set out in the review protocol were not available. We could not, therefore, identify specific subgroups of women who may benefit from AI use.

If the description of randomisation is used as a barometer of reporting trial quality, it appears that this has improved over time. For example, in the studies of the first generation AI aminoglutethimide, six of seven randomisations were categorised as unclear whereas only two of the seven third generation AI letrozole trials were considered as such.

\section{A U THORS' CONCLUSIONS}

\section{Implications for practice}

Historically, the treatment for advanced (metastatic) breast cancer has been with hormonal treatments such as tamoxifen or the progestins MA or MPA. This review confirms a survival benefit of treating advanced (metastatic) breast cancer with the third generation aromatase inhibitors (anastrozole, exemestane and letrozole) that are being used clinically today.

\section{Implications for research}

This review would benefit from additional publications with greater survival details, that is median survival and number of events, for those studies that did not publish them originally. Further data from exemestane trials are required to evaluate this AI more completely. Efforts should be made to standardise reporting of toxicity, and a quality of life component should also be included.

\section{ACKNOWLEDGEMENTS}

The authors were funded by Cancer Research UK. Lorna Gibson would like to thank Julian Peto and Isabel dos Santos Silva for their support. The authors would like to thank the Cochrane Breast Cancer Group for their support and are indebted to Olivia Fletcher for critical reading of the manuscript.

\section{R E F E R E N C E S}

\section{References to studies included in this review}

\section{Alonso-Munoz 1988 \{published data only\}}

Alonso-Munzo MC, Ojeda-Gonzalez M, Beltran-Fabregat M, Dorca-Ribugent J, Lopez-Lopez L, Borras-Balada J, et al.Randomized trial of tamoxifen versus aminoglutethimide and versus combined tamoxifen and aminoglutethimide in advanced postmenopausal breast cancer. Oncology 1988;45: $350-3$.

Bezwoda 1998 \{published data only\}

* Bezwoda WR, Gudgeon A, Falkson G, Jordaan JP, Goedhals L. Fadrozole versus megestrol acetate: a doubleblind randomised trial in advanced breast cancer. Oncology 1998;55:416-20.

Bonneterre 2001 \{published data only\}

* Bonneterre J, Buzdar A, Nabholtz JA, Robertson JFR,

Thuerlimann B, von Euler M, et al.Anastrozole is superior to tamoxifen as first-line therapy in hormone receptor positive advanced breast carcinoma. Cancer 2001;92(9): 2247-58.

Bonneterre J, Thuerlimann B, Robertson JFR, Krzakowski M, Mauriac L, Koralewski P, et al.Anastrozole versus tamoxifen as first-line therapy for advanced breast cancer in 668 postmenopausal women: results of the tamoxifen or arimidex randomized group efficacy and tolerability study. Journal of Clinical Oncology 2000;18(22):3748-57. Nabholtz JM. Advanced breast cancer updates on anastrozole versus tamoxifen. Journal of Steroid Biochemistry and Molecular Biology 2003;86:321-5.

Nabholtz JM, Bonneterre J, Buzdar A, Robertson JFR, Thuerlimann B. Anastrozole (Arimidex) versus tamoxifen as first-line therapy for advanced breast cancer in postmenopausal women: survival analysis and updated safety results. European Journal of Cancer 2003;39:1684-89. Nabholtz JM, Buzdar A, Pollak M, Harwin W, Burton G, Mangalik A, et al.Anastrozole is superior to tamoxifen as first-line therapy for advanced breast cancer in 
postmenopausal women: results of a North American multicenter randomized trial. Journal of Clinical Oncology 2000;18(22):3758-67.

Thuerlimann B, Robertson JFR, Nabholtz JM, Buzdar A, Bonneterre J. Efficacy of tamoxifen following anastrozole ('Arimidex') compared with anastrozole following tamoxifen as first-line treatment for advanced breast cancer in postmenopausal women. European Journal of Cancer 2003; 39:2310-17.

Vergote I, Bonneterre J, Thuerlimann B, Robertson J, MKrzakowski M, Mauriac L, et al.Randomised study of anastrozole versus tamoxifen as first-line therapy for advanced breast cancer in postmenopausal women. European Journal of Cancer 2000;36(Suppl:):81-91.

Buzdar 1996a \{published data only\}

* Budzar A, Jonat W, Howell A, Jones SE, Blomqvist C, Vogel CL, et al.Anastrozole, a potent and selective aromatase inhibitor, versus megestrol acetate in postmenopausal women with advanced breast cancer: results of overview analsyis of two phase III trials. Journal of Clinical Oncology 1996;14(2000 - 11).

Buzdar AU, Jonat W, Howell A, Jones SE, Blomqvist CP, Vogel CL, et al.Anastrozole versus megestrol acetate in the treatment of postmenopausal women with advanced breast carcinoma. Cancer 1998;83(6):1142-52.

Buzdar AU, Jonat W, Howell A, Plourde PV. Arimidex: a potent and selective aromatase inhibitor for the treatment of advanced breast cancer. Journal Steroid Biochemistry Molecular Biology 1997;61(3-6):145-9.

Drummond M, Thompton E, Howell A, Jonat W, Buzdar A, Brown J. Cost-effectiveness implications of increased survival with anastrozole in the treatment of advanced breast cancer. Journal of Medical Economics 1999;2:33-43. Jonat W, Howell A, Blomqvist C, Eiermann W, Winblad G, TyrrellC, et al.A randomized trial comparing two doses of the new selective aromatase inhibitor anastrozole (Arimidex) with megestrol acetate in postmenopausal women with advanced breast cancer. European Journal of Cancer 1996; 32A(3):404-12.

Robertson JFR, Howell A, Buzdar A, von Euler M, Lee D. Static disease on anastrozole provides similar benefit as objective response in patients with advanced breast cancer. Breast Cancer Research and Treatment 1999;58:157-62.

Buzdar 1996b \{published data only\}

* Buzdar A, Smith R, Vogel C, Bonomi P, Keller AM, Favis $\mathrm{G}$, et al.Fadrazole $\mathrm{HCl}$ (CGS-16949A) versus megestrol acetate in postmenopausal patients with metatatic breast carcinoma: results of two randomized, double-blind, controlled multi-institutional trials. Cancer 1996;77(12): 2503-13.

Buzdar 1996c \{published data only\}

Buzdar A, Smith R, Vogel C, Bonomi P, Keller AM, Favis G, et al.Fadrazole $\mathrm{HCl}$ (CGS-16949A) versus megestrol acetate in postmenopausal patients with metatatic breast carcinoma: results of two randomized, double-blind, controlled multiinstitutional trials. Cancer 1996;77(12):2503-13.
Buzdar 2001 \{published data only\}

* Buzdar A, Douma J, Davidson N, Elledge R, Morgan M, Smith R, et al.Phase III, multicenter, double-blind, randomized study of letrozole, an aromatase inhibitor, for advanced breast cancer versus megestrol acetate. Journal of Clinical Oncology 2001;19(14):3357-66.

Canney 1988 \{published data only\}

* Canney PA, Priestman TJ, Griffiths T, Latief TN, Mould JJ, Spooner D. Randomized trial comparing aminoglutethimide with high-dose medroxyprogesterone acetate in therapy for advanced breast carcinoma. Journal of the National Cancer Institute 1988;80(14):1147-51.

Dombernowsky 1998 \{published data only\}

* Dombernowsky P, Smith I, Falkson G, Leonard R, Panasci L, Bellmunt J, et al.Letrozole, a new oral aromatase inhibitor for advanced breast cancer: double-blind randomized trial showing a dose effect and improved efficacy and tolerability compared with megestrol acetate. Journal of Clinical Oncology 1998;16(2):453-61.

Falkson 1996 \{published data only\} * Falkson CI, Falkson HC. A randomised study of CGS 16949A (fadrozole) versus tamoxifen in previously untreated postmenopausal patients with metastatic breast cancer. Annals of Oncology 1996;7:465-69.

Gershanovich 1998 \{published data only\}

* Gershanovich M, Chaudri HA, Campos D, Lurie $\mathrm{H}$, Bonaventura A, Jeffrey $\mathrm{M}$, et al.Letrozole, a new oral aromatase inhibitor: randomised trial comparing $2.5 \mathrm{mg}$ daily, $0.5 \mathrm{mg}$ daily and aminoglutethimide in postmenopausal women with advanced breast cancer. Annals of Oncology 1998;9:639-45.

Gershanovitch M. Letrozole, a new aromatase for advanced breast cancer. Voprosy onkolgii 45;4:361-68.

Goss 1999 \{published data only\}

* Goss PE, Winer EP, Tannock IF, Schwarz LH. Randomized phase III trial comparing the new potent and selective third generation aromatase inhibitor vorozole with megestrol acetate in postmenopausal advanced breast cancer patients. Journal of Clinical Oncology 1999;17(1):52-63.

Ingle 1986 \{published data only\}

* Ingle JN, Green SJ, Ahmann DL, Long HJ, Edmonson $\mathrm{JH}$, Rubbin J, et al.Randomized trial of tamoxifen alone or combined with aminoglutethimide and hydrocortisone in women with metastatic breast cancer. Journal of Clinical Oncology 1986;4(6):958-64.

Kaufmann 2000 \{published data only\}

Hillner BE, Radice D. Cost-effectiveness analysis of exemestane compared with megestrol in patients with advanced breast carcinoma. Cancer 2001;91(3):484-89. Kaufmann M, Bajetta E, Dirix LY, Fein LE, Jones SE, Cervek J, et al.Exemestane improves survival compared with megestrol acetate in postmenopausal patients with advanced breast cancer who have failed on tamoxifen: results of a 
double-blind randomised phase III trial. European Journal of Cancer 2000;36(Suppl):81-91.

* Kaufmann M, Bajetta E, Dirix LY, Fein LE, Jones SE, Zilembo $\mathrm{N}$, et al.Exemestane is superior to megestrol acetate after tamoxifen failure in postmenopausal women with advanced breast cancer: results of a phase III randomised double-blind trial. Journal of Clinical Oncology 2000;18(7): 1399-1411.

Kleeberg 1997 \{published data only\}

* Kleeberg UR, Dowsett M, Carrion RP, Dodwell DJ, Vorobiof DA, Aparicio LA, Robertson JFR. A randomised comparison of oestrogen suppression with anastrozole and formestane in postmenopausal patients with advanced breast cancer. Oncology 1997;54(Suppl 2):19-22. Vorobiof DA, Kleeberg UR, Perez-Carrion R, Dodwell DJ, Robertson JFR, Calvo L, et al.A randomized, open, parallel-group trial to compare the endocrine effects of oral anastrozole (Arimidex) with intramuscular formestane in postmenopausal women with advanced breast cancer. Annals of Oncology 1999;10:1219-25.

Leitzel 1995 \{published data only\}

* Leitzel K, Teramoto Y, Konrad K, Chinchilli VM, Volas G, Grossberg H, et al.Elevated Serum c-erb B-2 Antigen Levels and decreased response to hormone therapy of breast cancer. Journal of Clinical Oncology 1995;13(5):1129-35.

Mauriac 2003 \{published data only\}

Howell A, Robertson JFR, Quaresma Albano J, Ascgermannova A, Mauriac L, Kleeberg UR, et al.Fulvestrant, formerly ICI 182, 780, is as effective as anastrozole in postmenopausal women with advanced breast cancer progressing after prior endocrine treatment. Journal of Clinical Oncology 2002;20(16):3396-403.

* Mauriac L, Pippen JE, Quaresma Albano J, Gertler SZ Osborne CK. Fulvestrant (Faslodex) versus anastrozole for the second-line treatment of advanced breast cancer in subgroups of postmenopausal women with visceral and nonvisceral metasteses: combined results from two multicentre trials. European Journal of Cancer 2003;39(9):1228-33. Osborne CK, Pippen J, Jones, SE, Parker LM, Ellis M, Come $S$, et al.Double-blind, randomized trial comparing the efficacy and tolerability of the fulvestrant versus anastrozole in postmenopausal women with advanced breast cancer progressing on prior endocrine therapy: results of a North American Trial. Journal of Clinical Oncology 2002;20 (16):3386-95.

Robertson JFR, Osborne CK, Howell A, Jones SE, Mauriac L, Ellis M, et al.Fulvestrant versus Anastrozole for the treatment of advanced breast carcinoma in postmenopausal women. Cancer 2003;98(2):229-38.

Vergote I. Fulvestrant versus anastrozole as second-line treatment of advanced breast cancer in postmenopausal women. European Journal of Cancer 2002; Vol. 38, issue 6:Suppl: $57-8$.

Mercer 1993 \{published data only\}

* Mercer PM, Ebbs SR, Fraser SCA, Coltart RS Bates T.

Trial of aminoglutethimide vs hydrocortisone as second-line hormone treatment of advanced breast cancer. European Journal of Surgical Oncology 1993;19:254-8.

Milla-Santos 2003 \{published data only\}

Milla-Santos A, Milla L, Portella J, Rallo L, Pons M, Rodes

$\mathrm{E}$, et al.Anastrozole versus tamoxifen as first-line therapy

in postmenopausal patients with hormone-dependent

advanced breast cancer. American Journal of Clinical

Oncology 2003;26(3):317-22.

Mourisden 2001 \{published data only\}

Mourisdan H, Sun Y, Gershanovich M, Perez-Carrion R, Becquart D, Chaudri-Ross HA, Lang R. Superiority of letrozole to tamoxifen in the first-line treatment of advanced breast cancer: evidence from metastatic subgroups and a test of functional ability. The Oncologist 2004;9:489-96. Mourisden H, Gershanovich M, Sun Y, Perez-Carrion R, Boni C, Monnier A, et al.Phase III study of letrozole versus tamoxifen as first-line therapy of advanced breast cancer in postmenopausal women: analysis of survival and update of efficacy from the International Letrozole Breast Cancer Group. Journal of Clinical Oncology 2003;21(11):2101-9. * Mourisden H, Gershanovich M, Sun Y, Perez-Carrion R, Boni C, Monnier A, et al.Superior efficacy of letrozole versus tamoxifen as first-line therapy for postmenopausal women with advanced brreast cancer: results of a phase III study of the international letrozole breast cancer group. Journal of Clinical Oncology 2001;19(10):2596-606.

Paridaens 2003 \{published data only\}

Atalay G, Dirix L, Biganzoli L, Beex L, Nooji M, Cameron $D$, et al.The effect of exemestane on serum lipid profile in postmenopausal women with metastatic breast cancer: a comparison study to EORTC Trial 10951, 'Randomized phase II study in first line hormonal treatment for metastatic breast cancer with exemestane or tamoxifen in postmenopausal patients'. Annals of Oncology 2004;15(2): 211-7.

* Paridaens R, Dirix L, Lohrisch C, Beex L, Nooji M, Cameron $\mathrm{D}$, et al.Mature results of a randomized phase II multicenter study of exemextane versus tamoxifen as first-line hormone therapy for postmenopausal women with metastatic breast cancer. Annals of Oncology 2003;14: 1391-8.

Perez Carrion 1994 \{published data only\}

* Perez Carrion R, Alberola Candel V, Calabresi F, Michel RT, Santos R, Delozier T, et al.Comparison of the selective aromatase inhibitor formestane with tamoxifen as first-line therapy in postmenopausal women with advanced breast cancer. Annals of Oncology 1994;5:Suppl 7 19-24.

Powles 1984 \{published data only\}

* Powles TJ, Ashley S, Ford HT, Gazet JC, Nash AG, Neville AM, Coombes RC. Treatment of disseminated breast cancer with tamoxifen, aminoglutethimide, hydrocortisone, and danazol, used in combination or sequentially. The Lancet 1984:1369-72.

Rose 1986 \{published data only\}

Rose C, Kamby C, Mouridsen HT, Andersson M, Bastholt $\mathrm{L}$, Moller KA, et al.Combined endocrine treatment of 
elderly postmenopausal patients with metastatic breast cancer. Breast Cancer Research and Treatment 2000;61(2): 103-10.

* Rose C, Kamby C, Mouridsen HT, Bastholt L, Brincker $\mathrm{H}$, Skovaard-Poulsen $\mathrm{H}$, et al.Combined endocrine treatment of postmenopausal patients with advanced breast cancer. A randomised trial of tamoxifen vs. tamoxifen plus aminoglutethimide and hydrocortisone. Breast Cancer Research and Treatment 1986;7:Suppl 45-50.

Rose 2003 \{published data only\}

* Rose C, Vtoraya O, Pluzanska A, Davidson N, Gershanovich M, Thomas R, et al.An open randomised trial of second-line endocrine therapy in advanced breast cancer. European Journal of Cancer 2003;39(16):2318-27. Tobias JS, Howell A. An open randomised trial of second-line endocrine therapy in advanced breast cancer: comparison of the Aromatase inhibitors letrozole and anastrozole. European Journal of Cancer 2004;40(12):1913.

Russell 1997 \{published data only\}

* Russell C, Green SJ, O'Sullivan J, Hynes HE, Budd T, Congdon JE, et al.Megestrol acetate and aminoglutethimide/hydrocortisone in sequence or in combination as second-line endocrine therapy of estrogen receptor-positive metastatic breast cancer: a southwest oncology group phase III trial. Journal of Clinical Oncology 1997;15(7):2494-501.

Schmid 2001 \{published data only\}

* Schmid P, Wischnewsky MB, Possinger K. Self organizing maps and prognosis of advanced breast cancer patients with bone metastases receiving letrozole or MA. Breast Cancer Research and Treament 2001;64:77.

Thuerlimann 1996 \{published data only\}

* Thuerlimann B, Beretta K, Bacchi M, Castiglione-Gertsch M, Goldhirsch A, Jungi WF, et al.First-line fadrozole HCI (CGS 16949A) versus tamoxifen in postmenopausal women with advanced breast cancer. Annals of Oncology 1996;7: 471-9.

Thuerlimann 1997 \{published data only\}

Bernhard J, Casiglione-Gertsch M, Hsu Schmitz S-F, Thuerlimann B, Cavalli F, Morant R, et al.Quality of life in postmenopausal patients with breast cancer after failure of tamoxifen: formestane versus megestrol acetate as secondline hormonal treatment. European Journal of Cancer 1999; 35(6):913-20.

Bernhard J, Thuerlimann B, Hsu Schmitz S-F, CastiglioneGertsch M, Cavalli F, Morant R, et al.Defining clinical benefit in postmenopausal patients with breast cancer under second-line endocrine treatment: does quality of life matter. Journal of Clinical Oncology 1999;17(6):1672-79.

* Thuerlimann B, Castiglione M, Hsu-Scmitz SF, Cavalli F, Bonnefoi H, Fey MF, et al.Formestane versus megestrol acetate in postmenopausal breast cancer patients after failure of tamoxifen: a phase III prospective randomised cross over trial of second-line hormonal treatment (SAKK 20/90).

European Journal of Cancer 1997;33(7):1017-24.
Tominaga 2003 \{published data only\}

* Tominaga T, Adachi I, Sasaki Y, Tabei T, Ikeda T,

Takatsuka Y, et al.Double-blind randomised trial comparing the non-steroidal aromatase inhibitors letrozole and fadrozole in postmenopausal women with advanced breast cancer. Annals of Oncology 2003;14:62-70.

\section{References to studies excluded from this review}

Abe 2002 \{published data only\}

* Abe R, Tominaga T, Nomizu T, Nomura Y, Takashima S, Koyama H, et al.CGS20267 (letrozole), a new aromatase inhibitor: late phase II study for postmenopausal women with advanced or recurrent breast cancer (no. 1) investigation of recommended clinical dose CGS20267 Study Group. Gan To Kaguku Ryoho 2002;29(5):729-40.

\section{Bajetta 1994 \{published data only\}}

* Bajetta E, Zilembo N, Buzzoni R, Noberasco C, Di Leo A, Bartoli $\mathrm{C}$, et al.Endocrinological and clinical evaluation of two doses of formestane in advanced breast cancer. British Journal of Cancer 1994;70:145-50.

Ferrari L, Zilembo N, Bajetta, Buzzoni R, Noberasco C, Martinetti A, et al.Effect of two 4-hydroxyandrostenedione doses on serum insulin-like growth factor I levels in advanced breast cancer. Breast Cancer Research and Treatment 1994;30:127-32.

Bajetta 1997 \{published data only\}

* Bajetta E, Zilembo N, Noberasco C, Martinetti A, Mariani L, Ferrari L, et al.The minimal effective exemestane dose for endocrine activity in advanced breast cancer. European Journal of Cancer 1997;33(4):587-91.

\section{Bajetta 1997a \{published data only\}}

* Bajetta E, Ferrari L, Celio L, Mariana L, Miceli R, Di Leo A, et al.The aromatase inhibitor letrozole in advanced breast cancer: effects on serum insulin-like growth factor (IGF)-I and IGF-binding protein-3 levels. Journal of steroid Biochemistry 1997;63(4-6):261-7.

Bajetta 1999 \{published data only\}

* Bajetta E, Zilembo N, Dowsett M, Guillevin L, Di Leo A, Celio L, et al.Double-blind, randomised, multicentre endocrine trial comparing two letrozole doses in postmenopausal breast cancer patients. European Journal of Cancer 1999;35(2):208-13.

Beretta 1990 \{published data only\}

* Beretta KR, Hoeffken K, Kvinnsland S, Trunet P, Chaudri HA, Bhatnagar AS, et al.CGS 16949A, a new aromatase inhibitor in the treatment of breast cancer- a phase I study. Annals of Oncology 1990;1(6):421-6.

Bruning 1989 \{published data only\}

* Bruning PF, Bonfer JMG, Hart AAM, van der Linden E, de Jong-Bakker M, Moolenaar AJ, Nooijen WJ. Low dose aminoglutethimide without hydrocortisone for the treatment of advanced postmenopausal breast cancer. European Journal of Clinical Oncology 1989;25(2):369-76.

Bruning 1990 \{published data only\}

* Bruning PF, Bonfrer JMG, Wildiers J, Jassem J, Beex LVAM, Schorangel J, Nooijen WJ. Second-line endocrine 
treatment of postmenopausal advanced breast cancer preliminary endocrine results of a 5-arm randomized phase II trial of medium vs low dose aminoglutethimide, with or without hydrocortisone vs hydrocortisone alone (EORTC 10861). Journal of Steroid Biochemistry 1990;37(6):1013-9.

Dixon 2000 \{published data only\}

* Dixon JM, Renshaw L, Bellamy C, Stuart M, HoctinBoes G, Miller WR. The effects of neoadjuvant anastrozole (Arimidex) on tumor volume in postmenopausal women with breast cancer: a randomized, double-blind, singlecenter study. Clinical Cancer Research 2000;6(6):2229-35.

\section{Dowsett 1989 \{published data only\}}

Dowsett M, Cunningham DC, Stein RC, Evans S, Dehennin L, Hedley A, Coombes RC. Dose-related endocrine effects and pharmokinetics of oral and intramuscular 4hydroxyandrostenedione in postmenopausal breast cancer patients. Cancer Research 1989;49:1306-12.

Dowsett 1990 \{published data only\}

* Dowsett M, Stein RC, Mehta A, Coombes RC. Potency and selectivity of the non-steroidal aromatase inhibitor CGS $16949 \mathrm{~A}$ in postmenopausal breast cancer patients. Clinical Endocrinology 1990;32:623-34.

Dowsett 1994 \{published data only\}

Bonnefoi HR, Smith IE, Dowsett M, Trunet, Houston SJ, da Luz RJ, et al.Therapeutic effects of the aromatase inhibitor fadrozole hydrochloride in advanced breast cancer. British Journal of Cancer 1996;73:539-42.

* Dowsett M, Smithers D, Moore J, Trunet PF, Coombes RC, Powles TJ, et al.Endocrine changes with the aromatase inhibitor fadrozole hydrochloride in breast cancer. European Journal of Cancer 1994;30A(10):1453-8.

Dowsett 1995 \{published data only\}

* Dowsett M, Jones A, Johnston SRD, Jacobs S, Trunet P, Smith IE. In vivo measturement of aromatase inhibition by letrozole (CGS 20267) in postmenopausal patients with breast cancer. Clinical Cancer Research 1995;1:1511-5.

Geisler 1996 \{published data only\}

* Geisler J, King N, Dowsett M, Ottestad L, Lundgren

$\mathrm{S}$, Walton P, et al.Influence of anastrozole (Arimidex), a selective, non-steroidal aromatase inhibitor, on in vivo aromatisation and plasma oestrogen levels in post menopausal women with breast cancer. British Journal of Cancer 1996;74:1286-91.

Geisler 2002 \{published data only\}

* Geisler J, Haynes B, Anker G, Dowsett M, Loenning PE. Influence of letrozole and anastrozole on totla body aromatization and plasma estrogen levels in postmenopausal breast cancer patients evaluated in a randomised, cross-over study. Journal of Clinical Oncology 2002;20(3):751-7.

Ingle 1997 \{published data only\}

* Ingle JN, Johnson PA, Suman VJ, Gerstner JB, Mailliard JA, Camoriano JK, et al.A randomized phase II trial of two dosage levels of letrozole as third-line hormonal therapay for women with metastatic breast carcinoma. Cancer 1997;80: $218-24$.
Johnston 1994 \{published data only\}

* Johnston SRD, Smith IE, Doody D, Jacobs S, Robertshaw $\mathrm{H}$, Dowsett M. Clinical and endocrine effects of the oral aromatase inhibitor vorozole in postmenopausal patients with advanced breast cancer. Cancer Research 1994;54: 5875-81.

\section{Miller 1996b \{published data only\}}

* Miller AA, Lipton A, Henderson IC, Navari R, Mulagha MT, Cooper J. Fadrozole hydrochloride in postmenopausal patients with metastatic breast carcinoma. Cancer 1996;78: 789-93.

Pronzato 1993 \{published data only\}

* Pronzato P, Rubagotti A, Amoroso D, Bertelli G, Queirolo P, Sertoli MR, Rosso M, et al.Second-line hormone therapy for breast cancer. Uselessness of first-line continuation. American Journal of Clinical Oncology 1993;16(6):522-5.

Raats 1992 \{published data only\}

Falkson G, Raats JI, Falkson H. Fadrozole hydrochloride, a new nontoxic aromatase inhibitor for the treatment of patients with metastatic breast cancer. Journal of Steroid and Biochemistry and Molecular Biology 1992;43(1-3):161-5.

* Raats JI, Falkson G, Falkson H. A study of fadrozole, a new aromatase inhibitor, in postmenopasual women with advanced metastatic breast cancer. Journal of Clinical Oncology 1992;10(1):111-6.

Svenstrup 1994 \{published data only\}

* Svenstrup B, Herrstedt J, Bruenner N, Bennet P, Wachmann H, Dombernowsky P. Sex hormone levels in postmenopausal women with advanced metastatic breast cancer treated with CGS 169 49A. European Journal of Cancer 1994;30A(9):1254-8.

Wang 2003 \{published data only\}

* Wang HQ, Ren CC, Feng WJ, Lin MB, Xiong YQ, Huang P, Zhao WH, Hao XS, Chen SB, Yan Z. Treatment of advanced metastatic breast cancer with exemestane, a multicenter randomized controlled study of 195 cases. Zhonghua Yi Xue Za Zhi 2003;83(3):188-90.

\section{References to ongoing studies}

\section{ECOG E4101 \{published data only\}} ECOG E4101. Ongoing study Starting date of trial not provided. Contact author for more information.

Efect \{published data only\} Efect

Phase III. Ongoing study Starting date of trial not provided. Contact author for more information.

ICR-CTSU Sofea \{published data only\} Sofea

Phase III. Ongoing study March 2004.

Paridaens 2003 \{published data only\} Phase III EORTC-10951. Ongoing study Starting date of trial not provided. Contact author for more information.

\section{Additional references}




\section{Beatson 1896}

Beatson GT. On the treatment of inoperable cases of carcinoma of the mamma. Suggestions for a new method of treatment with illustrative cases. Lancet 1896;2:104-7.

Ferlay 2000

Ferlay J, Bray F, Pisani P, Parkin DM. Globocan 2000: Cancer Incidence, Mortality and Prevalence Worldwide. 1. Lyon: IARC Press, 2001.

Hayward 1977

Hayward JL, Carbone PP, Heuson JC, Kumaoka S, Segaloff A, Rubens RD. Assessment of response to therapy in advanced breast cancer: a project of the Programme on Clinical Oncology of the International Union Against Cancer, Geneva, Switzerland. Cancer 1977;39(3):1289-94.

Howell 1997

Howell A, Dowsett M. Recent advances in endocrine therapy of breast cancer. British Medical Journal 1997;315: 863-6.

Ibrahim 1995

Ibrahim NK, Buzdar AU. Aromatase inhibitors: current status. American Journal of Clinical Oncology 1995;18(5): 407-17.

\section{Jonat 1996}

Jonat W, Howell A, Blomqvist C, et al.A randomized trial comparing two doses of the new selective aromatase inhibitor anastrazole (Arimidex) with megestrol acetate in postmenopausal women with advanced breast cancer. European Journal of Cancer 1996;32A:404-412.

\section{Miller 1996a}

Miller WR. Aromatase inhibitors. Endocrine-related Cancer 1996;3:65-79.

\section{Parmar 1995}

Parmar MKB, Machin D. Survival analysis: A Practical Approach. John Wiley, 1995.

\section{Roseman 1997}

Roseman BJ, Buzdar AU, Singletary SE. Use of aromatase inhibitors in postmenopausal women with advanced breast cancer. Journal of Surgical Oncology 1997;66:215-20.

* Indicates the major publication for the study 


\section{CHARACTERISTICS OF STUDIES}

\section{Characteristics of included studies [ordered by study ID]}

\section{Alonso-Munoz 1988}

\begin{tabular}{|c|c|c|}
\hline Methods & \multicolumn{2}{|c|}{$\begin{array}{l}\text { Spain, multicentre, } \mathrm{N}=105 \text {, Dec } 1982-\text { Dec } 1985 \\
\text { Three arm study (only two arms included in review } \mathrm{N}=70 \text { ) } \\
\text { Randomisation method not given } \\
\text { Baseline characteristics balanced }\end{array}$} \\
\hline Participants & \multicolumn{2}{|c|}{$\begin{array}{l}\text { Age range } 37-75 \\
\text { Proven metastatic breast cancer, measurable disease sites } \\
\text { No previous endocrine therapy }\end{array}$} \\
\hline Interventions & \multicolumn{2}{|c|}{$\begin{array}{l}\text { AG }(500 \mathrm{mg} \text { for } 2 \mathrm{w} \text {, then } 100 \mathrm{mg}) \text { v TAM } 40 \mathrm{mg} \text { v AG }+ \text { TAM } 40 \mathrm{mg} \\
\text { Numbers in each treatment arm: } 35 \mathrm{v} 35 \mathrm{v} 35 \\
\text { (AG+TAM arm data excluded from review } \mathrm{N}=35 \text { ) } \\
\text { Assessable patients (two included arms): } 31 \mathrm{v} 34 \\
\text { Patients evaluable for toxicity (two included arms): } 33 \text { v } 34\end{array}$} \\
\hline Outcomes & \multicolumn{2}{|c|}{$\begin{array}{l}\text { Toxicity, TTP, response rate } \\
\text { Not survival }\end{array}$} \\
\hline Notes & \multicolumn{2}{|c|}{$\begin{array}{l}11 \text { not evaluable ( } 4 \text { AG, } 6 \text { TAM }+ \text { AG, } 1 \text { TAM) due to: } 4 \text { died within } 6 \text { w, } 1 \text { discontinued treatment, } 5 \\
\text { toxicity, } 1 \text { lost to FU } \\
\text { FU duration not given } \\
\text { TTP not given by treatment arm }\end{array}$} \\
\hline \multicolumn{3}{|l|}{ Risk of bias } \\
\hline Item & Authors' judgement & Description \\
\hline Allocation concealment? & Unclear & B - Unclear \\
\hline
\end{tabular}

Bezwoda 1998

\begin{tabular}{ll}
\hline Methods & South Africa, multicentre, $\mathrm{N}=96$ \\
& $\begin{array}{l}\text { Double-blind, double-dummy } \\
\text { Balanced block stratification by centre } \\
\text { Baseline slight imbalance in ER status: } 28 \% \mathrm{v} 20 \% \mathrm{ER}+\end{array}$ \\
\hline Participants & $\begin{array}{l}\text { Age range } 44-82 \\
\text { Measurable or evaluable metastatic breast cancer } \\
\text { Prior TAM treatment } \\
\text { No previous treatment with AI } \\
\text { ECOG perf status }<3\end{array}$ \\
\hline
\end{tabular}


Bezwoda 1998 (Continued)

\begin{tabular}{|c|c|c|}
\hline Interventions & \multicolumn{2}{|c|}{$\begin{array}{l}\text { fadrozole } 2 \mathrm{mg} \text { v MA } 160 \mathrm{mg} \\
\text { Numbers in each treatment arm: } 46 \mathrm{v} 50 \\
\text { Assessable patients: } 46 \mathrm{v} 50 \\
\text { Patients evaluable for toxicity: } 46 \mathrm{v} 50 \\
\text { Treatment until progression or for } 1 \mathrm{y} \text {; median duration } 20 \mathrm{w}\end{array}$} \\
\hline Outcomes & \multicolumn{2}{|c|}{$\begin{array}{l}\text { Primary - response rate, TTP, TTF, survival } \\
\text { Secondary - QOL, performance status, pain assessment }\end{array}$} \\
\hline Notes & \multicolumn{2}{|c|}{$\begin{array}{l}\text { FU to relapse or death } \\
\text { Median FU not stated } \\
\text { Intention to treat analysis } \\
\text { Subsidiary analysis on a per protocol basis ( } 41 \mathrm{v} 43) \\
7 \text { major protocol violations, } 2 \text { refusals, } 1 \text { early death, } 1 \text { lost to FU (numbers not consistent) }\end{array}$} \\
\hline \multicolumn{3}{|l|}{ Risk of bias } \\
\hline Item & Authors' judgement & Description \\
\hline Allocation concealment? & Yes & A - Adequate \\
\hline
\end{tabular}

Bonneterre 2001

\begin{tabular}{|c|c|}
\hline Methods & $\begin{array}{l}\text { International, multicentre study, Feb } 1996 \text { - July 1998, combined results of two trials } \\
97 \text { sites in US and Canada, N = } 353 \\
83 \text { sites in Europe, Australia, New Zealand, South Africa, South America, N = } 668 \\
\text { Total randomised = } 1021 \\
\text { Double-blind, double-dummy } \\
\text { Baseline characteristics well-balanced }\end{array}$ \\
\hline Participants & $\begin{array}{l}\text { Age range } 30-92 \\
\text { Advanced or metastatic breast cancer }\end{array}$ \\
\hline Interventions & $\begin{array}{l}\text { anastrozole } 1 \mathrm{mg} \text { v TAM } 20 \mathrm{mg} \\
\text { Numbers in each treatment arm: } 171 \text { v } 182 \text { (N America) and } 340 \text { v } 328 \text { (rest of world) } \\
\text { Assessable patients: } 511 \text { v } 510 \\
\text { Patients evaluable for toxicity: } 506 \text { v } 511 \\
\text { Treatment continued until disease progression }\end{array}$ \\
\hline Outcomes & $\begin{array}{l}\text { Primary - objective response, TTP, tolerability } \\
\text { Secondary - TTF, survival }\end{array}$ \\
\hline Notes & $\begin{array}{l}\text { FU to progression and death } \\
\text { Median FU not known } \\
\text { Number of dropouts not given }\end{array}$ \\
\hline
\end{tabular}

\section{Risk of bias}


Bonneterre 2001 (Continued)

\begin{tabular}{l|ll}
\hline Item & Authors' judgement & Description \\
\hline Allocation concealment? & Yes & A - Adequate \\
\hline
\end{tabular}

\section{Buzdar 1996a}

\begin{tabular}{|c|c|c|}
\hline Methods & \multicolumn{2}{|c|}{$\begin{array}{l}\text { International, multicentre. } 122 \text { centres: } 49 \text { in North America, } 73 \text { in Europe, Australia, South Africa, } \\
\text { Double-blind anastrozole, open megestrol acetate } \\
\text { Randomisation method - blocks of } 6 \text { (Europe), blocks of } 3 \text { ( } \mathrm{N} \text { America), parallel groups } \\
\text { Two trials combined }(\mathrm{N}=764) \text { : North America }(\mathrm{N}=346) \text { and Europe, Australia, South Africa }(\mathrm{N}=378) \\
\text { Three arm study (only two arms included in review } \mathrm{N}=516) \\
\text { Baseline: apparent imbalance in one treatment group (believed to be artefact) }\end{array}$} \\
\hline Participants & \multicolumn{2}{|c|}{$\begin{array}{l}\text { Age range } 29 \text { - } 97 \\
\text { Advanced breast cancer } \\
\text { Progressed on anti-oestrogen for advanced disease or progressed on or during adjuvant TAM } \\
\text { WHO perf status }<3\end{array}$} \\
\hline Interventions & \multicolumn{2}{|c|}{$\begin{array}{l}\text { anastrozole } 1 \mathrm{mg} \text { v anastrozole } 10 \mathrm{mg} \text { v MA } 160 \mathrm{mg} \\
\text { Numbers in each treatment arm: } 263 \text { v } 248 \text { v } 253 \\
\text { (anastrozole } 10 \mathrm{mg} \text { arm excluded from review } \mathrm{N}=248 \text { ) } \\
\text { Assessable patients (two included arms): } 263 \mathrm{v} 253 \\
\text { Patients evaluable for toxicity (two included arms): } 262 \mathrm{v} 253 \\
\text { Treatment continued until disease progression or withdrawal from treatment for other reasons }\end{array}$} \\
\hline Outcomes & \multicolumn{2}{|c|}{$\begin{array}{l}\text { Primary - TTP, tumour response, tolerability } \\
\text { Secondary - TTF, response duration, survival } \\
\text { Clinical assessment every } 4 \mathrm{w} \text { until week } 24 \text {, every } 12 \mathrm{w} \text { until week } 48 \text { then every } 3 \mathrm{~m} \text { until progression }\end{array}$} \\
\hline Notes & \multicolumn{2}{|c|}{$\begin{array}{l}\text { FU median duration } 6 \mathrm{~m} \\
3 \text { no treatment, } 1 \text { wrong treatment, } 8 \text { lost to FU } \\
\text { Intention to treat analysis }\end{array}$} \\
\hline \multicolumn{3}{|l|}{ Risk of bias } \\
\hline Item & Authors' judgement & Description \\
\hline Allocation concealment? & Yes & A - Adequate \\
\hline
\end{tabular}


Buzdar 1996b

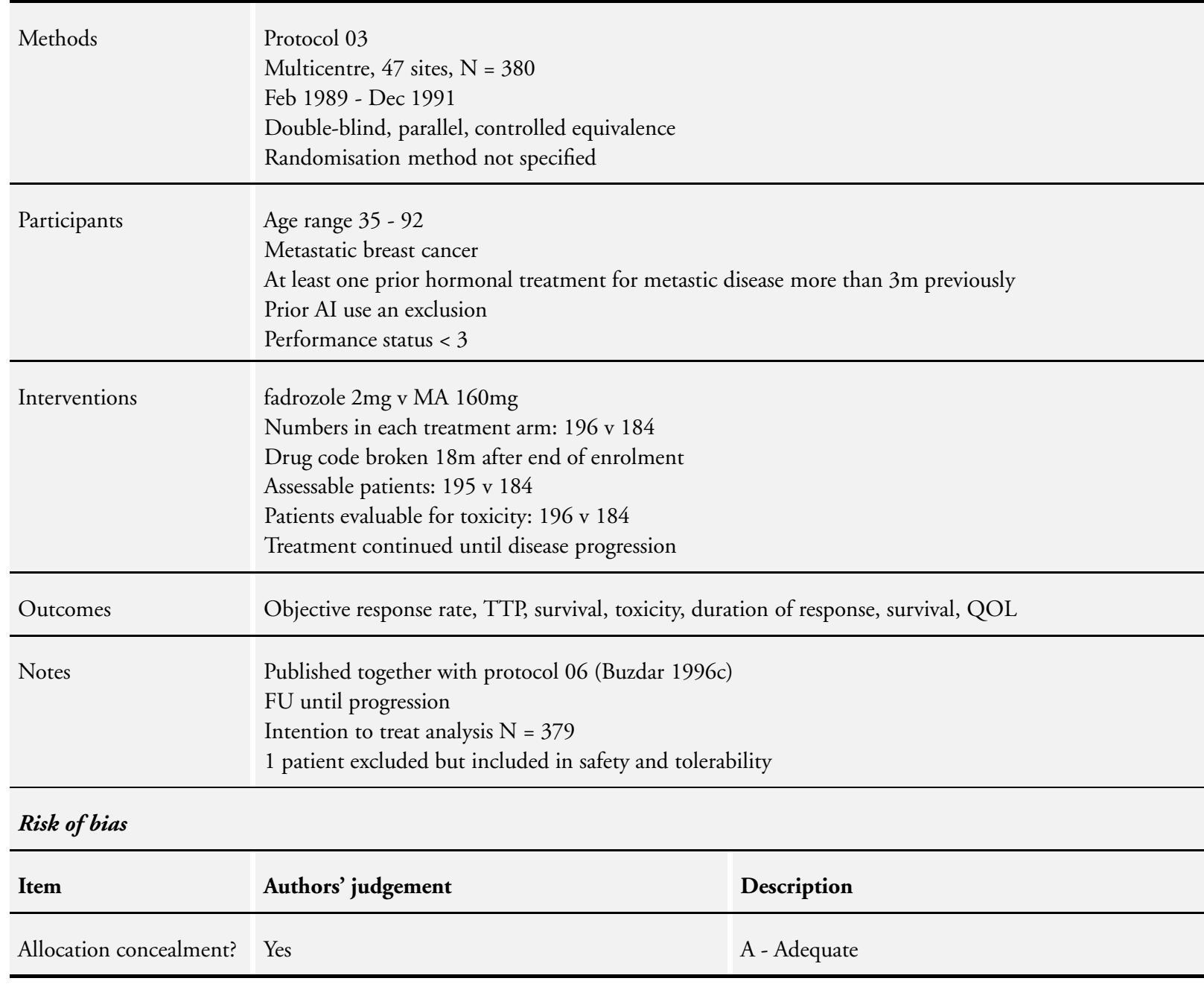

Buzdar 1996c

\begin{tabular}{ll}
\hline Methods & $\begin{array}{l}\text { Protocol } 06 \\
\text { Multicentre, } 55 \text { sites, } \mathrm{N}=303 \\
\text { Oct } 1989 \text { - Aug } 1992 \\
\text { Double-blind, parallel, controlled equivalence } \\
\text { Randomisation method not specified }\end{array}$ \\
\hline Participants & $\begin{array}{l}\text { Age range } 36-92 \\
\text { Metastatic breast cancer } \\
\text { At least one prior hormonal treatment for metastic disease more than } 3 \mathrm{~m} \text { previously } \\
\text { Prior AI use an exclusion } \\
\text { Performance status<3 }\end{array}$ \\
\hline Interventions & $\begin{array}{l}\text { fadrozole } 2 \mathrm{mg} \text { v MA } 160 \mathrm{mg} \\
\text { Numbers in each treatment arm: } 152 \mathrm{v} 151\end{array}$
\end{tabular}


Buzdar 1996c (Continued)

Assessable patients: $150 \mathrm{v} 148$

Patients evaluable for toxicity: 152 v 151

Drug code broken $18 \mathrm{~m}$ after end of enrolment

Treatment continued until disease progression

Outcomes $\quad$ Primary - overall tumour response (TTP, TTF, survival)

other - earliest diagnosis of PD, tolerability, safety, QOL

Notes

Published together with protocol 03 (Buzdar 1996b)

FU: $33 \mathrm{~m}$ for tumour response/safety (median $5.5 \mathrm{~m}$ )

$45 \mathrm{~m}$ for survival (median 18 to $20 \mathrm{~m}$ )

Intention to treat analysis $\mathrm{N}=298$

Not designed or powered to detect differences in survival

\section{Risk of bias}

\begin{tabular}{lll} 
Item & Authors' judgement & Description \\
\hline Allocation concealment? & Yes & A - Adequate \\
\hline
\end{tabular}

Buzdar 2001

Methods

International, multicentre, 120 sites in US, Canada, Europe, $\mathrm{N}=602$

Three arm study (only two arms inculded in review $\mathrm{N}=400$ )

Double-blind, double dummy, phase III

Randomisation by country w/o stratification by centre

Enrolment over 30 months

Baseline characteristics no imbalance

Age range not given
Locally advanced/locoregionally recurrent/metastatic breast cancer
At least one measurable/assessable lesion
Relapsed or progressed while on anti-oestrogen or relapsed within $12 \mathrm{~m}$ of stopping antioestrogen
Chemotherapy for advanced disease allowed
$\mathrm{KPF}>=50 \%$

Interventions letrozole $2 \mathrm{mg} v$ letrozole $10 \mathrm{mg}$ v MA $160 \mathrm{mg}$

Numbers in each treatment arm: 202 v 199 v 201

(letrozole $2 \mathrm{mg}$ arm excluded from review $\mathrm{N}=202$ )

Assessable patients: 182 v 180

Patients evaluable for toxicity: 199 v 201

Treatment continued until disease progression or withdrawal for other reason

Outcomes

Primary - tumour response

Secondary - TTF, TTP, survival, QOL 
Buzdar 2001 (Continued)

\begin{tabular}{|c|c|c|}
\hline Notes & \multicolumn{2}{|c|}{$\begin{array}{l}\text { FU period } 48 \mathrm{~m} \text { after the first visit of the last patient randomised } \\
\text { Intention to treat analysis } \\
23 \text { ineligible and excluded from tumour analyses }\end{array}$} \\
\hline \multicolumn{3}{|l|}{ Risk of bias } \\
\hline Item & Authors' judgement & Description \\
\hline Allocation concealment? & Yes & A - Adequate \\
\hline \multicolumn{3}{|l|}{ Canney 1988} \\
\hline Methods & \multicolumn{2}{|c|}{$\begin{array}{l}\text { UK, number of centres not given, } N=218 \\
\text { Randomised without stratification, performed centrally by phone over } 24 \mathrm{~m}\end{array}$} \\
\hline Participants & \multicolumn{2}{|c|}{$\begin{array}{l}\text { Median age } 64 \\
\text { Actively progressive disease } \\
\text { Received hormonal therapy with tamoxifen } \\
\text { Received no anticancer therapy within preceding } 4 \mathrm{w}\end{array}$} \\
\hline Interventions & \multicolumn{2}{|c|}{$\begin{array}{l}\text { AG }(250 \mathrm{mg} \text { for } 2 \mathrm{w} \text {, increased to } 500 \mathrm{mg} \text { if not toxic effect plus } 40 \mathrm{mg} \mathrm{HC}) \mathrm{v} \text { high dose MPA } 1000 \mathrm{mg} \\
\text { Numbers in each treatment arm: } 106 \mathrm{v} 112 \\
\text { Patients evaluable for toxicity: } 106 \mathrm{v} 112\end{array}$} \\
\hline Outcomes & \multicolumn{2}{|c|}{ Duration of response, survival, time to response } \\
\hline Notes & \multicolumn{2}{|c|}{$\begin{array}{l}\text { FU duration: minumum } 9 \mathrm{~m} \text {, median } 55 \mathrm{w} \text { for } \mathrm{AG}, 57 \mathrm{w} \mathrm{MPA} \\
7 \text { patients either violated protocol or did not meet entry criteria but included in analyses } \\
\text { Crossover on failure } \\
\text { No variation between groups in known prognostic variables. }\end{array}$} \\
\hline \multicolumn{3}{|l|}{ Risk of bias } \\
\hline Item & Authors' judgement & Description \\
\hline Allocation concealment? & Yes & A - Adequate \\
\hline
\end{tabular}


Dombernowsky 1998

\begin{tabular}{|c|c|c|}
\hline Methods & \multicolumn{2}{|c|}{$\begin{array}{l}\text { International, multicentre, Mar } 1993 \text { - Sep } 1994 \\
10 \text { countries, } 91 \text { sites, } N=551 \\
\text { Three arm study (only two arms included in review } N=363 \text { ) } \\
\text { Double-blind, randomisation stratified by country; computer-generated permuted blocks of size } 6 \text { or 3, } \\
\text { 1:1:1 allocation } \\
\text { Baseline characteristics balanced }\end{array}$} \\
\hline Participants & \multicolumn{2}{|c|}{$\begin{array}{l}\text { Advanced/locoregionally recurrent/metastatic breast cancer } \\
\text { Measurable/assessable disease } \\
\text { Failure to respond to previous anti-oestrogen } \\
\text { WHO perf status }<3\end{array}$} \\
\hline Interventions & \multicolumn{2}{|c|}{$\begin{array}{l}\text { letrozole } 0.5 \mathrm{mg} \text { v letrozole } 2.5 \mathrm{mg} \text { v MA } 160 \mathrm{mg} \\
\text { Numbers in each treatment arm: } 188 \mathrm{v} 174 \mathrm{v} 189 \\
\text { (letrozole } 0.5 \mathrm{mg} \text { arm excluded from review } \mathrm{N}=188 \text { ) } \\
\text { Assessable patients: } 153 \mathrm{v} 166 \\
\text { Patients evaluable for toxicity: } 174 \mathrm{v} 189\end{array}$} \\
\hline Outcomes & \multicolumn{2}{|c|}{$\begin{array}{l}\text { Primary - overall tumour response (TTP, TTF, survival) } \\
\text { Other - earliest diagnosis of PD, tolerability, safety }\end{array}$} \\
\hline Notes & \multicolumn{2}{|c|}{$\begin{array}{l}\text { FU: } 33 \mathrm{~m} \text { for tumour response/safety (median } 5.5 \mathrm{~m} \text { ) } \\
45 \mathrm{~m} \text { for survival (median } 18 \text { to } 20 \mathrm{~m} \text { ) } \\
\text { Intention to treat analysis } \\
\text { Not designed or powered to detect differences in survival as significant }\end{array}$} \\
\hline \multicolumn{3}{|l|}{ Risk of bias } \\
\hline Item & Authors' judgement & Description \\
\hline Allocation concealment? & Yes & A - Adequate \\
\hline
\end{tabular}

Falkson 1996

Methods

South Africa, single centre, $\mathrm{N}=80$

Sep 1991 - Dec 1994

Randomisation method not given

Baseline: difference of $10 \mathrm{y}$ in median age of patients in arm $1 \mathrm{v}$ arm 2

\begin{tabular}{ll} 
Participants & $\begin{array}{l}\text { Age range } 43-90 \\
\text { Progressive, inoperable, recurrent or metas } \\
\text { No prior treatment for advanced disease } \\
\text { ECOG }<3\end{array}$ \\
\hline Interventions & $\begin{array}{l}\text { fadrozole } 2 \mathrm{mg} \text { v TAM } 20 \mathrm{mg} \\
\text { Numbers in each treatment arm: } 40 \mathrm{v} 40 \\
\text { Assessable patients: } 36 \text { v } 38 \\
\text { Patients evaluable for toxicity: } 40 \mathrm{v} 40\end{array}$
\end{tabular}

Aromatase inhibitors for treatment of advanced breast cancer in postmenopausal women (Review) 
Falkson 1996 (Continued)

Minimum treatment $8 \mathrm{w}$

Outcomes Survival, TTF, duration of overall response, toxicity, objective response rates,

\begin{tabular}{|c|c|c|}
\hline Notes & $\begin{array}{l}\text { FU } 14 \text { to } 1122 \mathrm{~d} \text {, median FU } 153 \mathrm{~d} \\
\text { Intention to treat analysis } \\
2 \text { ineligible, } 1 \text { lost to FU } \\
74 \text { patients evaluable }\end{array}$ & \\
\hline \multicolumn{3}{|l|}{ Risk of bias } \\
\hline Item & Authors' judgement & Description \\
\hline Allocation concealment? & Unclear & B - Unclear \\
\hline
\end{tabular}

Gershanovich 1998

\begin{tabular}{|c|c|c|}
\hline Methods & \multicolumn{2}{|c|}{$\begin{array}{l}\text { International, multicentre, } 11 \text { countries, } 86 \text { sites } \mathrm{N}=555 \\
\text { Three arm study (only two arms included in review } \mathrm{N}=363 \text { ) } \\
\text { Open-label 1:1:1 } \\
\text { Baseline no major differences }\end{array}$} \\
\hline Participants & \multicolumn{2}{|c|}{$\begin{array}{l}\text { Median age letrozole } 2.5 \mathrm{mg} 66 \mathrm{y} \text {, letrozole } 0.5 \mathrm{mg} 64 \mathrm{y} \text {, AG } 65 \mathrm{y} \\
\text { Advanced or metastatic breast cancer } \\
\text { Measurable/evaluable advanced disease } \\
\text { WHO perf status }<3\end{array}$} \\
\hline Interventions & \multicolumn{2}{|c|}{$\begin{array}{l}\text { letrozole } 2.5 \mathrm{mg} \text { v letrozole } 0.5 \mathrm{mg} \text { v AG } 500 \mathrm{mg} \\
\text { Numbers in each treatment arm: } 185 \mathrm{v} 192 \mathrm{v} 178 \\
\text { (letrozole } 2.5 \mathrm{mg} \text { arm excluded from review } \mathrm{N}=192 \text { ) } \\
\text { Assessable patients: } 173 \mathrm{v} 162\end{array}$} \\
\hline Outcomes & \multicolumn{2}{|c|}{ Response, TTP, TTF, survival, tolerability and safety, overall survival } \\
\hline Notes & \multicolumn{2}{|c|}{$\begin{array}{l}\text { FU duration median }>20 \mathrm{~m} \\
44 \text { not assessable } \& \text { counted as non-responders in the analysis } \\
\text { Median duration of treatment } 5 \mathrm{~m} \\
\text { Modified intention to treat population ie enrolled and received study medication }\end{array}$} \\
\hline \multicolumn{3}{|l|}{ Risk of bias } \\
\hline Item & Authors' judgement & Description \\
\hline Allocation concealment? & Unclear & B - Unclear \\
\hline
\end{tabular}


Goss 1999

Methods

Nov 1991 - Dec 1995

Multicentre, 29 sites in Canada and 38 in US, $\mathrm{N}=452$

Open-label, stratified by disease status

Baseline characteristics comparable

$\begin{array}{ll}\text { Participants } & \text { Age range } 39-90 \\ \text { Advanced breast cancer, histologically confirmed } \\ \text { Progressed after tamoxifen treatment }\end{array}$

Interventions $\quad$ vorozole $2.5 \mathrm{mg}$ v MA $160 \mathrm{mg}$

Numbers in each treatment arm: 225 v 227

Assessable patients: 190 v 185

Patients evaluable for toxicity: 195 v 198

2nd line treatment after tamoxifen

Outcomes Primary - response rate

Secondary - TTP, survival, duration of response, safety subjective symptoms, QOL

Notes $\quad$ Median FU 11.6m (vorozole) $9.9 \mathrm{~m}$ (MA)

1 withdrawn before treatment

4 ineligible, 18 Adverse Events, 1 lost to FU, 18 other

\section{Risk of bias}

\begin{tabular}{lll}
\hline Item & Author' judgement & Description \\
\hline Allocation concealment? & Yes & A - Adequate \\
\hline
\end{tabular}

\section{Ingle 1986}

\begin{tabular}{l|l}
\hline Methods & $\begin{array}{l}\text { US, number of centres not known, } \mathrm{N}=102 \\
\text { Randomised using Pocock-Simon approach to adaptive randomisation, stratified }\end{array}$ \\
\hline Participants & $\begin{array}{l}\text { Age range } 38-83 \\
\text { Progressive metastatic disease } \\
\text { Measurable or evaluable lesion } \\
\text { ECOG perf status < } 4 \\
\text { No prior therapy with either AG or TAM }\end{array}$ \\
\hline Interventions & $\begin{array}{l}\text { TAM } 20 \mathrm{mg} \text { v TAM (20mg) }+ \text { AG }(500 \mathrm{mg} \text { for } 2 \text { weeks then } 1000 \mathrm{mg})+\text { HC }(100 \mathrm{mg} \text { daily for } 2 \text { weeks } \\
\text { then } 40 \mathrm{mg}) \\
\text { Numbers in each treatment arm: } 49 \text { v } 51 \\
\text { Assessable patients: } 49 \mathrm{v} 51 \\
\text { Patients evaluable for toxicity: } 48 \text { v } 46\end{array}$ \\
\hline Outcomes & \begin{tabular}{l} 
Objective response, TTP, survival, toxicity \\
\hline
\end{tabular}
\end{tabular}


Ingle 1986 (Continued)

\begin{tabular}{|c|c|c|}
\hline Notes & \multicolumn{2}{|c|}{$\begin{array}{l}\text { No data on duration of FU } \\
\text { Target accrual }=160 \text { but terminated early due to excess toxicity on the TAM }+\mathrm{AG}+\mathrm{HC} \text { arm } \\
2 \text { patients ineligible }\end{array}$} \\
\hline \multicolumn{3}{|l|}{ Risk of bias } \\
\hline Item & Authors' judgement & Description \\
\hline Allocation concealment? & Unclear & B - Unclear \\
\hline
\end{tabular}

Kaufmann 2000

\begin{tabular}{|c|c|c|}
\hline Methods & \multicolumn{2}{|l|}{$\begin{array}{l}\text { International, multicentre, Oct } 1995 \text { - May } 1998 \text {, } \\
19 \text { countries, } 144 \text { centres } \mathrm{N}=769 \\
\text { Double-blind, parallel-group, phase III } \\
\text { Baseline characteristics comparable }\end{array}$} \\
\hline Participants & \multicolumn{2}{|l|}{$\begin{array}{l}\text { Age range } 30-91 \\
\text { Advanced breast cancer } \\
\text { Progressed or relapsed during tamoxifen treatment }\end{array}$} \\
\hline Interventions & \multicolumn{2}{|l|}{$\begin{array}{l}\text { exemestane } 25 \mathrm{mg} \text { v MA } 160 \mathrm{mg} \\
\text { Numbers in each treatment arm: } 366 \text { v } 403 \\
\text { Assessable patients: } 337 \text { v } 366 \\
\text { Patients evaluable for toxicity: } 358 \text { v } 400\end{array}$} \\
\hline Outcomes & \multicolumn{2}{|c|}{$\begin{array}{l}\text { Objective response, TTP, TTF, survival, tumour response, duration of tumour control, tumour related } \\
\text { signs and symptoms, QOL, tolerability }\end{array}$} \\
\hline Notes & \multicolumn{2}{|l|}{$\begin{array}{l}\text { FU median duration } 48.9 \mathrm{w} \\
6 \text { randomised but not treated } \\
66 \text { not evaluable for tumour response } \\
\text { Intention to treat analysis }\end{array}$} \\
\hline \multicolumn{3}{|l|}{ Risk of bias } \\
\hline Item & Authors' judgement & Description \\
\hline Allocation concealment? & Yes & A - Adequate \\
\hline
\end{tabular}


Kleeberg 1997

\begin{tabular}{|c|c|c|}
\hline Methods & \multicolumn{2}{|c|}{$\begin{array}{l}\text { International, multicentre, } 27 \text { Jun - } 1 \text { Dec } 1995 \\
18 \text { centres, Europe and South Africa, N = } 60 \\
\text { open label, parallel group, comparative } \\
\text { Baseline good balance re age, weight, prior tamoxifen treatment }\end{array}$} \\
\hline Participants & \multicolumn{2}{|c|}{$\begin{array}{l}\text { Age range } 40-84 \\
\text { Advanced breast cancer } \\
\text { Measurable or evaluable disease }\end{array}$} \\
\hline Interventions & \multicolumn{2}{|c|}{$\begin{array}{l}\text { anastrozole } 1 \mathrm{mg} \text { oral per day v formestane } 250 \mathrm{mg} \text { im every } 2 \mathrm{w} \\
\text { Numbers in each treatment arm: } 29 \mathrm{v} 31 \\
\text { Assessable patients: } 29 \mathrm{v} 31 \\
\text { Treatment until disease progression }\end{array}$} \\
\hline Outcomes & \multicolumn{2}{|c|}{$\begin{array}{l}\text { Primary - oestradiol suppression and tolerability } \\
\text { Secondary - response rates, TTP, adverse events, blood oestrone sulphate, patient and doctor perception } \\
\text { of treatment }\end{array}$} \\
\hline Notes & \multicolumn{2}{|c|}{$\begin{array}{l}\text { No details re randomisation exclusions or FU } \\
\text { Not powered to detect clinically significant difference in oestrogen suppression between the two arms }\end{array}$} \\
\hline \multicolumn{3}{|l|}{ Risk of bias } \\
\hline Item & Authors' judgement & Description \\
\hline Allocation concealment? & Unclear & B - Unclear \\
\hline
\end{tabular}

Leitzel 1995

Methods

Location and date of study not given

Multicentre, $\mathrm{N}=300$

Double-blind, double-dummy, parallel

Randomisation method not given

\begin{tabular}{ll}
\hline Participants & Age range $18-85$ \\
& Metastatic breast cancer \\
& ECOG $<3$ \\
\hline
\end{tabular}

Interventions fadrozole $2 \mathrm{mg} \mathrm{v}$ MA $160 \mathrm{mg}$

Numbers in each treatment arm not given

duration of intervention not given

Second-line treatment

\begin{tabular}{l|l}
\hline Outcomes & Tumour response, progression, c-erbB-2 Antigen in serum \\
\hline Notes & $\begin{array}{l}\text { FU until death } \\
\text { Results not given by treatment group } \\
\text { Survival was not given by treatment group although it was measured }\end{array}$
\end{tabular}

Aromatase inhibitors for treatment of advanced breast cancer in postmenopausal women (Review) 
Leitzel 1995 (Continued)

Risk of bias

\begin{tabular}{|c|c|c|}
\hline Item & Authors' judgement & Description \\
\hline Allocation concealment? & Yes & A - Adequate \\
\hline
\end{tabular}

Mauriac 2003

\begin{tabular}{|c|c|c|}
\hline Methods & \multicolumn{2}{|c|}{$\begin{array}{l}\text { Data were combined and published from two trials } 0020 \text { and } 0021 \text { (May } 1997 \text { - September 1999) } \\
\text { Trial 0020: multicentre, phase III, open, parallel group } \\
\text { Europe, Australia and South Africa, } 83 \text { centres, } N=451 \\
\text { Trial 0021: multicentre, phase III, double blind, double dummy, parallel group } \\
\text { North America, } \mathrm{N}=400 \\
\text { Combined data from both trials included in review } \mathrm{N}=851\end{array}$} \\
\hline Participants & \multicolumn{2}{|c|}{$\begin{array}{l}\text { Age range } 33-89 \\
\text { Locally advance or metastatic breast cancer } \\
\text { Progressed during adjuvant endocrine therapy or first-line therapy for advanced disease } \\
\text { WHO performance status }<3\end{array}$} \\
\hline Interventions & \multicolumn{2}{|c|}{$\begin{array}{l}\text { fulvestrant } 250 \mathrm{mg} / \mathrm{month} \text { im v anastrozole } 1 \mathrm{mg} \\
\text { Trial 0020: Numbers in each treatment arm: } 222 \mathrm{v} 229 \\
\text { Trial 0020: Numbers in each treatment arm: } 206 \mathrm{v} 194 \\
\text { Combined trials (included in review): Numbers in each treatment arm: } 423 \text { v } 428 \\
\text { Assessable patients: } 423 \mathrm{v} 428 \\
\text { Patients evaluable for toxicity: } 423 \mathrm{v} 423 \\
\text { Continued until objective disease progression or other events required withdrawal }\end{array}$} \\
\hline Outcomes & \multicolumn{2}{|c|}{ TTP, Objective response, tolerability, QOL } \\
\hline Notes & \multicolumn{2}{|c|}{$\begin{array}{l}\text { Combined data median FU } 15.1 \mathrm{~m} \\
\text { Intention to treat analysis } \\
\text { Additional to protocol noninferiority of fulvestrant with anastrozole was carried out retrospectively }\end{array}$} \\
\hline \multicolumn{3}{|l|}{ Risk of bias } \\
\hline Item & Authors' judgement & Description \\
\hline Allocation concealment? & Yes & A - Adequate \\
\hline
\end{tabular}


Mercer 1993

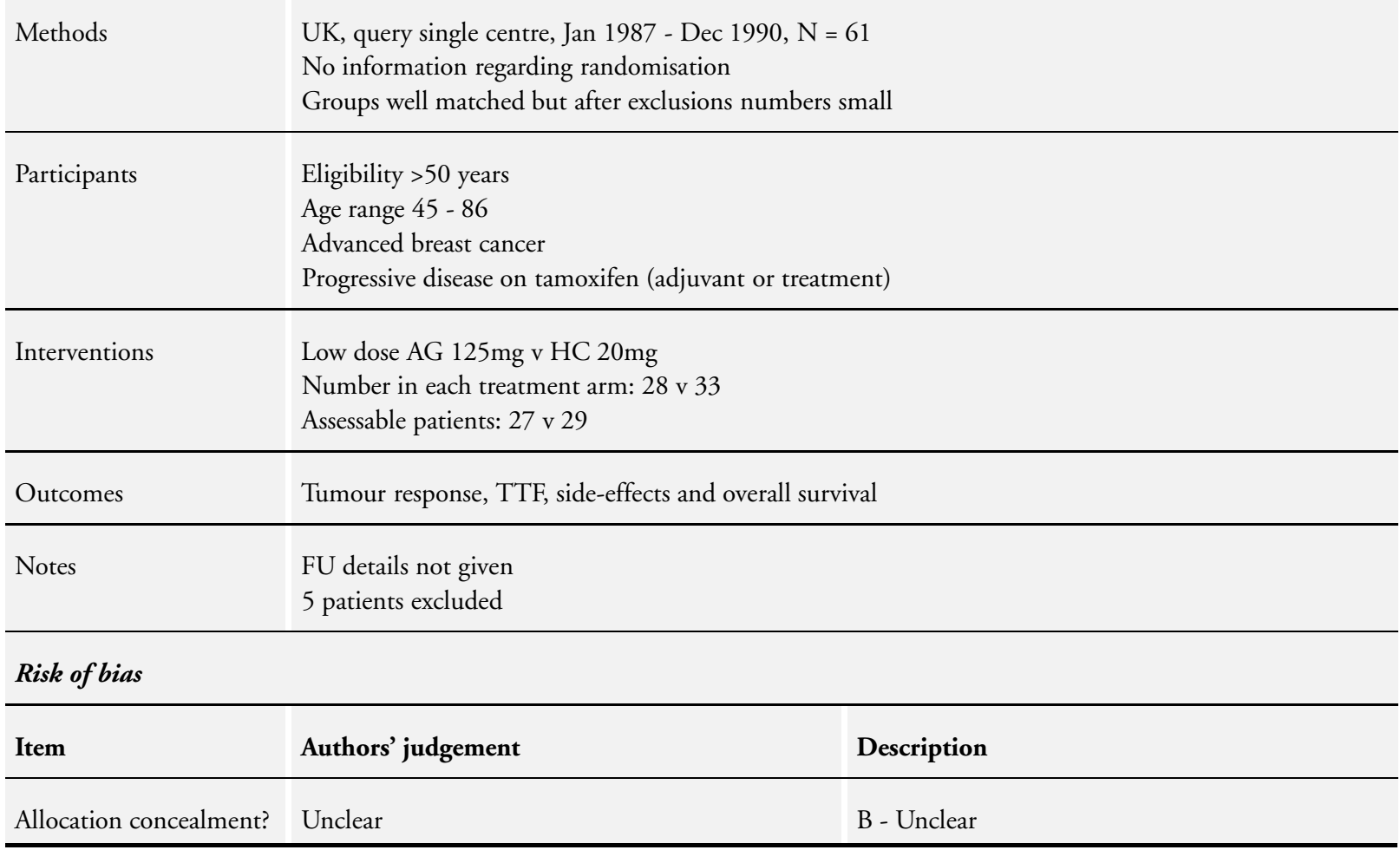

Milla-Santos 2003

\begin{tabular}{l|l}
\hline Methods & $\begin{array}{l}\text { Spain, single centre, N }=238, \text { May 1997 - Dec 1999 } \\
\text { Randomisation following Meinert's methodology. } \\
\text { Baseline characteristics comparable }\end{array}$ \\
\hline Participants & $\begin{array}{l}\text { Age range } 55-77 \\
\text { Histologicaly confirmed advanced breast cancer, measurable disease sites } \\
\text { No previous endocrine therapy } \\
\text { ECOG<3 }\end{array}$ \\
\hline Interventions & $\begin{array}{l}\text { anastrozole } 1 \text { mg v TAM } 40 \mathrm{mg} \\
\text { Assessable patients: } 121 \mathrm{v} 117\end{array}$ \\
\hline Outcomes & $\begin{array}{l}\text { Primary - response rates, clinical benefit, TTP in patients achieving a CB, overall survival, toxicity } \\
\text { Notes }\end{array}$ \\
\hline $\begin{array}{l}\text { FU to } 35 \mathrm{~m} \\
\text { intention to treat analysis } \\
\text { All patients evaluable } \\
\text { Analysis cutoff } 1 \text { April } 2001\end{array}$ \\
\hline
\end{tabular}

Risk of bias 


\begin{tabular}{|c|c|c|}
\hline Item & Authors' judgement & Description \\
\hline Allocation concealment? & Unclear & B - Unclear \\
\hline
\end{tabular}

Mourisden 2001

Methods International, multicentre, Nov 1996 - Jan 1999

29 countries, 201 sites, $\mathrm{N}=939$

Double-blind, double-dummy, parallel group

Baseline characteristics well-balanced

\begin{tabular}{ll} 
Participants & $\begin{array}{l}\text { Age range } 31-96 \\
\text { Locally advanced/locoregionally recurrent/metastatic breast cancer which is measurable/assessable } \\
\text { Previous chemotherapy allowed for advanced disease } \\
\text { WHO perf status < } 3\end{array}$ \\
\hline Interventions & $\begin{array}{l}\text { letrozole } 2.5 \mathrm{mg} \text { v TAM } 20 \mathrm{mg} \\
\text { Numbers in each treatment arm: } 453 \mathrm{v} 454 \\
\text { Assessable patients: } 421 \mathrm{v} 423 \\
\text { Patients evaluable for toxicity: } 455 \mathrm{v} 455 \\
\text { Treatment continued until disease progression }\end{array}$ \\
\hline Outcomes & $\begin{array}{l}\text { Primary - TTP } \\
\text { Secondary - tumour response rate, TTF, ORR, survival, tolerability, KPS }\end{array}$ \\
\hline Fu median $32 \mathrm{~m}$ \\
Intention to treat analysis \\
907 analysed, 32 excluded \\
Analysis cutoff March 2000 \\
Survival not reported \\
729 discontinued treatment of which 391 'crossed over'
\end{tabular}

Risk of bias

\begin{tabular}{l|ll}
\hline Item & Authors' judgement & Description \\
\hline Allocation concealment? & Yes & A - Adequate \\
\hline
\end{tabular}


13 centres in 6 countries, $\mathrm{N}=122$

Open-label phase II, randomised centrally using minimization by EORTC, stratified by centre, adjuvant TAM, CT for metastatic disease, dominant disease site

The trial was designed as a randomised phase II study not to enable comparison of the efficacy of the two drugs but to establish a 'go, no-go' rule for exemestane activity and safety before a formal randomised phase III trial. Patients randomised into the phase II study will be incorporated into the phase III study

\begin{tabular}{|c|c|}
\hline Participants & $\begin{array}{l}\text { Age range } 37-87 \\
\text { measurable metastatic or locally recurrent inoperable breast cancer } \\
\text { No prior hormone therapy for metastatic disease } \\
\text { ECOG perf status }<3\end{array}$ \\
\hline Interventions & $\begin{array}{l}\text { exemestane } 25 \mathrm{mg} \text { v TAM } 20 \mathrm{mg} \\
\text { Numbers in each treatment arm: } 62 \text { v } 60 \\
\text { Intention to treat analysis: } 61 \mathrm{v} 59 \\
\text { Toxicity data: } 62 \mathrm{v} 59 \\
\text { Assessable patients: } 56 \text { v } 57 \\
\text { Patients evaluable for toxicity: } 62 \text { v } 59 \\
\text { Treatment continued until disease progression }\end{array}$ \\
\hline Outcomes & $\begin{array}{l}\text { Response rates } \\
\text { Stop go for phase III } \\
\text { Phase II therefore inadequate power, no statistical comparison of efficacy of endpoints between the two } \\
\text { treatments were planned or performed }\end{array}$ \\
\hline Notes & $\begin{array}{l}\text { FU details } \\
2 \text { patients ( } 1 \text { exemestane, } 1 \text { TAM) ineligible as not having metastatic breast cancer, } 7 \text { additional (5 } \\
\text { exemestane, } 2 \text { TAM) not evaluable for response, } 1 \text { lost to FU } \\
\text { Phase II patients to be included in phase III study } \\
\text { Intention to treat analysis }\end{array}$ \\
\hline
\end{tabular}

\section{Risk of bias}

\begin{tabular}{l|ll}
\hline Item & Authors' judgement & Description \\
\hline Allocation concealment? & Yes & A - Adequate \\
\hline
\end{tabular}

Perez Carrion 1994

Methods International, multicentre, May 1988 - December 1990, N = 409

Open study, equivalence trial

Baseline characteristics well matched

Participants

Age range $38-87$

WHO perf status $<3$ 


\section{Perez Carrion 1994 (Continued)}

\begin{tabular}{|c|c|c|}
\hline Interventions & \multicolumn{2}{|l|}{$\begin{array}{l}\text { formestane } 250 \mathrm{mg} \text { im v TAM } 30 \mathrm{mg} \\
\text { Numbers in each treatment arm: } 203 \text { v } 206 \\
\text { Assessable patients: } 173 \text { v } 175\end{array}$} \\
\hline Outcomes & \multicolumn{2}{|l|}{ Response, survival, TTP, TTF, tolerability } \\
\hline Notes & \multicolumn{2}{|c|}{$\begin{array}{l}\text { FU details not reported } \\
61 \text { patients not evaluable, } 10 \text { lost to FU, } 3 \text { refusals } \\
\text { Intention to treat analysis } \\
\text { Trial closed early due to changes in clinical practice, ie increasing use of TAM in the adjuvant setting }\end{array}$} \\
\hline \multicolumn{3}{|l|}{ Risk of bias } \\
\hline Item & Authors' judgement & Description \\
\hline Allocation concealment? & Unclear & B - Unclear \\
\hline
\end{tabular}

Powles 1984

\begin{tabular}{|c|c|c|}
\hline Methods & \multicolumn{2}{|c|}{$\begin{array}{l}\text { Sept } 1979 \text { - June } 1983 \\
\text { UK, single centre, } \mathrm{N}=222 \\
\text { Previously determined allocation list unknown to clinician. } \\
\text { Baseline characteristics mean age marginally greater for TAM patients }\end{array}$} \\
\hline Participants & \multicolumn{2}{|c|}{$\begin{array}{l}\text { Patients with disseminated breast cancer who had not previously received TAM, AG or danazol } \\
\text { No endocrine or chemotherapy within } 6 \mathrm{w}\end{array}$} \\
\hline Interventions & \multicolumn{2}{|c|}{$\begin{array}{l}\text { TAM } 20 \mathrm{mg} \text { v TAM } 20 \mathrm{mg}+\text { AG } 750 \mathrm{mg}+\text { danazol } 300 \mathrm{mg}+\text { HC } 40 \mathrm{mg} \\
\text { Number on each treatment arm: } 111 \mathrm{v} 111 \\
\text { Assessable patients: } 99 \mathrm{v} 99 \\
\text { Patients evaluable for toxicity: } 111 \mathrm{v} 111 \\
\text { Treatment continued until } 3 \mathrm{~m} \text { assessment (unless rapid development of tumour in meantime) otherwise } \\
\text { stopped when evidence of tumour progression arose either through failure to respond or because of relapse } \\
\text { after response or stabilisation of disease }\end{array}$} \\
\hline Outcomes & \multicolumn{2}{|l|}{ Tumour response } \\
\hline Notes & \multicolumn{2}{|c|}{ FU duration not reported } \\
\hline \multicolumn{3}{|l|}{ Risk of bias } \\
\hline Item & Authors' judgement & Description \\
\hline Allocation concealment? & Unclear & B - Unclear \\
\hline
\end{tabular}




\begin{tabular}{|c|c|}
\hline Methods & $\begin{array}{l}\text { Denmark, multicentre, June } 1979 \text { - Sept } 1988,4 \text { centres } \mathrm{N}=313 \\
\text { Three arm study (only two arms included in review } \mathrm{N}=215 \text { ) } \\
\text { Randomised by centre, non-stratified, stochastic array of numbers, closed envelope system } \\
\text { Baseline characteristics well balanced }\end{array}$ \\
\hline Participants & $\begin{array}{l}\text { Age }>65 \text {, age range } 66-84 \\
\text { First recurrence of metastatic breast cancer } \\
\text { Progressive disease with measurable and/or evaluable lesions } \\
\text { Performance status }<4\end{array}$ \\
\hline Interventions & $\begin{array}{l}\text { TAM } 30 \mathrm{mg} \text { v TAM } 30 \mathrm{mg}+\text { AG } 250 \mathrm{mg} \text { qid }+ \text { HC } 60 \mathrm{mg} \text { v TAM } 30 \mathrm{mg}+\text { fluoxymesterone } 20 \mathrm{mg} \\
\text { Numbers in each treatment arm: } 108 \mathrm{v} 107 \mathrm{v} 98 \\
\text { (TAM + fluoxymesterone excluded from review } \mathrm{N}=98 \text { ) } \\
\text { Assessable patients: } 83 \mathrm{v} 94 \\
\text { Patients evaluable for toxicity: } 87 \mathrm{v} 97 \\
\text { Treatment until progression (minimum } 12 \text { weeks) }\end{array}$ \\
\hline Outcomes & TTF, TTP, survival, toxicity \\
\hline Notes & $\begin{array}{l}\text { FU duration not reported } \\
34 \text { ineligible } \\
21 \text { not evaluable } \\
9 \text { lost to FU } \\
258 \text { fully evaluable }\end{array}$ \\
\hline
\end{tabular}

\section{Risk of bias}

\begin{tabular}{|c|c|c|}
\hline Item & Authors' judgement & Description \\
\hline Allocation concealment? & Unclear & B - Unclear \\
\hline
\end{tabular}

Rose 2003

Methods International phase IIIb/IV, 19 countries, multicentre, 112 sites, $\mathrm{N}=713$

Dec 1997 - Nov 1999

Open, random assignation stratified by centre via predetermined randomisation list Baseline characteristics well balanced

Participants
Advanced or metastatic breast cancer with measurable and/or evaluable disease
Histologically/cytologically confirmed
Previous treatment with anti-oestrogen
WHO performance status $0-2$

Interventions letrozole $2.5 \mathrm{mg} \mathrm{v}$ anastrozole $1 \mathrm{mg}$

Numbers in each treatment arm: 356 v 357

Assessable patients: 299 v 304 
Rose 2003

\begin{tabular}{|c|c|c|}
\hline Outcomes & \multicolumn{2}{|c|}{$\begin{array}{l}\text { Primary - TTP } \\
\text { Secondary- objective response, duration of response, rate and duration of overall clinical benefit, overall } \\
\text { survival, general safety }\end{array}$} \\
\hline Notes & \multicolumn{2}{|c|}{ FU duration not reported } \\
\hline \multicolumn{3}{|l|}{ Risk of bias } \\
\hline Item & Authors' judgement & Description \\
\hline Allocation concealment? & Yes & A - Adequate \\
\hline
\end{tabular}

\section{Russell 1997}

Methods

May 1984 - November 1990, Phase III, N = 288

Three arm study (only two arms included in review $\mathrm{N}=155$ )

No stratification

Treatment arms reasonably well balanced

\begin{tabular}{|c|c|}
\hline Participants & $\begin{array}{l}\text { Age range } 33-92 \\
\text { Progressive metastatic disease } \\
\text { Measurable or evaluable lesion } \\
\text { Patients had received TAM in advanced setting } \\
\text { No prior MA or AG }\end{array}$ \\
\hline Interventions & $\begin{array}{l}\text { MA } 160 \mathrm{mg} \text { v AG }(500 \mathrm{mg} \text { for } 2 \mathrm{w} \text { then } 1000 \mathrm{mg})+\mathrm{HC}(100 \mathrm{mg} \text { for } 2 \mathrm{w} \text { then } 40 \mathrm{mg}) \text { v MA } 160 \mathrm{mg}+\mathrm{AG} \\
(500 \mathrm{mg} \text { for } 2 \mathrm{w} \text { then } 1000 \mathrm{mg})+\text { hydrocortisone } \\
\text { Numbers in each treatment arm: } 75 \mathrm{v} 80 \mathrm{v} 80 \\
\text { (MA } 160 \mathrm{mg}+\mathrm{AG}(500 \mathrm{mg} \text { for } 2 \mathrm{w} \text { then } 1000 \mathrm{mg})+\text { hydrocortisone arm data excluded from review } \mathrm{N}= \\
80 \text { ) } \\
\text { Assessable patients: } 42 \mathrm{v} 32 \\
\text { Patients evaluable for toxicity: } 88 \mathrm{v} 89\end{array}$ \\
\hline Outcomes & Response, TTF, survival, toxicity \\
\hline Notes & $\begin{array}{l}\text { FU median duration amongst those still alive }=5.2 \mathrm{y}(213 \text { had died }) \\
53 \text { ineligible ( } 38 \text { re misunderstanding re prior TAM use, } 7 \text { due to life threatening visceral involvement, } 3 \\
\text { with less than } 6 \text { months of TAM, } 2 \text { ER -, } 1 \text { prior hormonal therapy other than TAM, } 1 \text { no confirmed } \\
\text { disease sites) } \\
\text { Patients on MA or AG alone were crossed over after progression }\end{array}$ \\
\hline
\end{tabular}

Risk of bias

\begin{tabular}{l|ll}
\hline Item & Authors' judgement & Description \\
\hline Allocation concealment? & Unclear & B - Unclear \\
\hline
\end{tabular}

Aromatase inhibitors for treatment of advanced breast cancer in postmenopausal women (Review) 
Schmid 2001

Methods

International, multicentre, $\mathrm{N}=171$

Three arm study (only two arms included in review $\mathrm{N}=112$ )

Double-blind

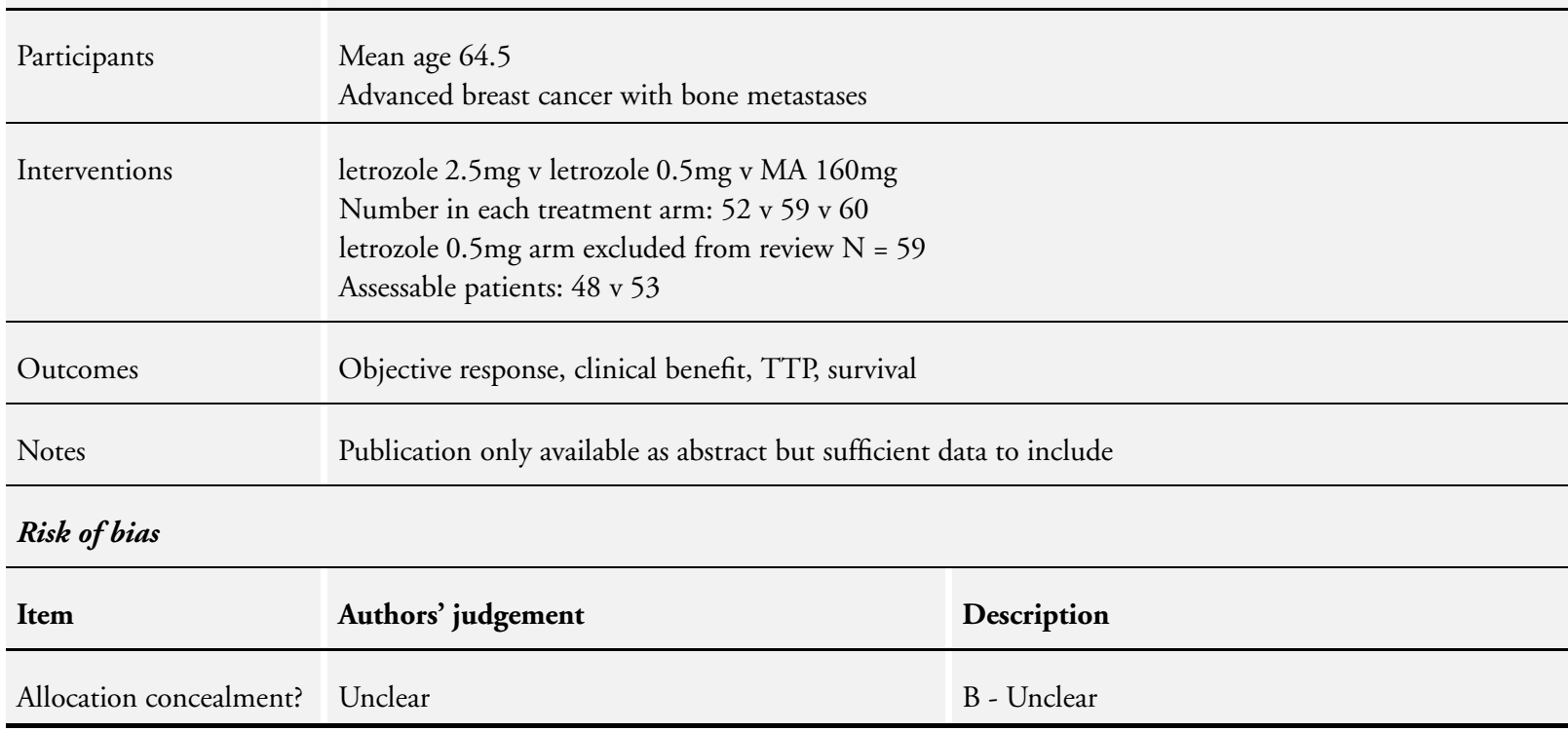

Thuerlimann 1996

\begin{tabular}{|c|c|}
\hline Methods & $\begin{array}{l}\text { Switzerland, Phase III multicentre, } 7 \text { sites, N = } 221 \\
\text { June } 1988 \text { - Dec } 1994 \\
\text { Phone randomisation, stratified, minimisation not double blind } \\
\text { Baseline: prognostic factors well-balanced apart from metastatic site }\end{array}$ \\
\hline Participants & $\begin{array}{l}\text { Age range } 39-87 \\
\text { Measurable/evaluable advanced breast cancer } \\
\text { Indication for hormone treatment } \\
\text { ECOG }<2\end{array}$ \\
\hline Interventions & $\begin{array}{l}\text { fadrozole } 2 \mathrm{mg} \text { v TAM } 20 \mathrm{mg} \\
\text { Numbers in each treatment arm: } 111 \mathrm{v} 110 \\
\text { Eligible patients: } 105 \mathrm{v} 107 \\
\text { Assessable patients: } 103 \mathrm{v} 106 \\
\text { Patients evaluable for toxicity: } 104 \mathrm{v} 107 \\
\text { First-line treatment } \\
\text { Treatment until progression }\end{array}$ \\
\hline Outcomes & TTF, response rate, toxicity, overall survival, TTP, subjective benefit (not reported), duration of response \\
\hline Notes & $\begin{array}{l}\text { FU } 71 / 2 \text { y } \\
\text { Eligible patients: } 212 \\
9 \text { ineligible( } 6 \text { fadrozole, } 3 \text { TAM) } \\
12 \text { withdrawals } \\
\text { Crossover only after failure so not analysed }\end{array}$ \\
\hline
\end{tabular}


Thuerlimann 1996 (Continued)

Analysis on data to Dec 1995, median FU of survivors 3y

\section{Risk of bias}

\begin{tabular}{|c|c|c|}
\hline Item & Authors' judgement & Description \\
\hline Allocation concealment? & Yes & A - Adequate \\
\hline
\end{tabular}

Thuerlimann 1997

\begin{tabular}{l|l}
\hline Methods & $\begin{array}{l}\text { Feb } 1991 \text { - Jun } 1995, \mathrm{~N}=179 \\
\text { Stratified } \\
\text { Baseline characteristics well-balanced (only difference in weight) }\end{array}$ \\
\hline Participants & $\begin{array}{l}\text { Age range } 43 \text { - } 87 \\
\text { Advanced breast cancer } \\
\text { Histologically and/or cytologically proven with measurable/evaluable disease } \\
\text { Failed prior adjuvant and/or palliative tamoxifen treatment ie second-line treatment } \\
\text { Prior chemotherapy allowed } \\
\text { ECOG perf status < 3 }\end{array}$ \\
\hline Interventions & $\begin{array}{l}\text { formestane } 250 \mathrm{mg} \text { im (biweekly) v MA } 160 \mathrm{mg} \\
\text { Numbers in each treatment arm: } 91 \mathrm{v} 86 \\
\text { Assessable patients: } 90 \mathrm{v} 83 \\
\text { Patients evaluable for toxicity: } 90 \mathrm{v} 81\end{array}$ \\
\hline Outcomes & TTF, toxicity \\
\hline Notes & $\begin{array}{l}\text { FU duration not reported } \\
2 \text { ineligible, } 4 \text { dropouts } \\
173 \text { fully evaluable } \\
\text { After failure of randomised treatment } 75 \text { patients 'crossed over' }\end{array}$ \\
\hline
\end{tabular}

\section{Risk of bias}

\begin{tabular}{|c|c|c|}
\hline Item & Authors' judgement & Description \\
\hline Allocation concealment? & Unclear & B - Unclear \\
\hline
\end{tabular}

\section{Tominaga 2003}

$\begin{array}{ll}\text { Methods } & \text { Japan, multicentre, } 62 \text { sites, } \mathrm{N}=157 \\ \text { Double blind, double dummy, parallel groups } \\ \text { Adaptive dynamic balancing method }\end{array}$


Tominaga 2003 (Continued)

\begin{tabular}{|c|c|c|}
\hline Participants & \multicolumn{2}{|c|}{$\begin{array}{l}\text { Mean age } 59.7 \text { (letrozole) and } 61.0 \text { (fadrozole) } \\
\text { Advanced disease } \\
\text { Measurable or assessable pathological lesions }\end{array}$} \\
\hline Interventions & \multicolumn{2}{|c|}{$\begin{array}{l}\text { letrozole } 1 \mathrm{mg} \text { v fadrozole } 2 \mathrm{mg} \\
\text { Numbers in each treatment arm: } 79 \text { v } 78 \\
\text { Assessable patients: } 77 \text { v } 77 \\
\text { Minimum } 8 \mathrm{w} \text { treatment } \\
\text { Treatment until disease progressed or patient experienced toxicity resulting in discontinuation }\end{array}$} \\
\hline Outcomes & \multicolumn{2}{|c|}{ ORR, safety of letrozole compared to fadrozole } \\
\hline Notes & \multicolumn{2}{|l|}{ FU median $13.3 \mathrm{~m}$} \\
\hline \multicolumn{3}{|l|}{ Risk of bias } \\
\hline Item & Authors' judgement & Description \\
\hline Allocation concealment? & Yes & A - Adequate \\
\hline
\end{tabular}

KPS - Karnofsky Performance Status

AG - aminoglutethimide

AI - aromatase inhibitor

$\mathrm{CB}$ - clinical benefit

ECOG - Eastern Cooperative Oncology Group

EORTC - European Organization for the Research and Treatment of Cancer

ER - oestrogen receptor

FU - follow up

im - intramuscular

mg - milligram

TAM - tamoxifen

MA - megestrol acetate

MPA - medroxy progesterone acetate

HC - hydrocortisone

$\mathrm{N}$ - number of patients

ORR - objective response rate

$\mathrm{PD}$ - progressive disease

perf status - performance status

qid - four times daily

QOL - quality of life

TTF - time to failure

TTP - time to progression

d - days

$\mathrm{w}$ - weeks

$\mathrm{m}$ - months

$\mathrm{y}$ - years

WHO - World Health Organisation 
w/o - without

Characteristics of excluded studies [ordered by study ID]

\begin{tabular}{|c|c|}
\hline Study & Reason for exclusion \\
\hline Abe 2002 & dose comparison of same AI (letrozole) \\
\hline Bajetta 1994 & dose comparison of same AI (formestane) \\
\hline Bajetta 1997 & dose comparison of same AI (exemestane) \\
\hline Bajetta 1997a & dose comparison of same AI (letrozole) \\
\hline Bajetta 1999 & dose comparison of same AI (letrozole) \\
\hline Beretta 1990 & dose comparison of same AI (letrozole) \\
\hline Bruning 1989 & dose comparison of same AI (aminoglutethimide) \\
\hline Bruning 1990 & dose comparison of same AI (aminoglutethimide) \\
\hline Dixon 2000 & dose-comparison of same AI (anastrozole) \\
\hline Dowsett 1989 & dose-comparison of same AI (formestane) \\
\hline Dowsett 1990 & dose-comparison of same AI (fadrozole) \\
\hline Dowsett 1994 & dose-comparison of same AI (fadrozole) \\
\hline Dowsett 1995 & dose-comparison of same AI (letrozole) \\
\hline Geisler 1996 & outcome: aromatase levels and plasma oestrogen levels \\
\hline Geisler 2002 & outcome: aromatase levels and plasma oestrogen levels \\
\hline Ingle 1997 & dose comparison of same AI (letrozole) \\
\hline Johnston 1994 & dose comparison of same AI (vorozole) \\
\hline Miller 1996b & dose comparison of same AI (fadrozole) \\
\hline Pronzato 1993 & AI (aminoglutethimide) versus same AI plus tamoxifen \\
\hline Raats 1992 & dose comparison of same AI (fadrozole) \\
\hline Svenstrup 1994 & dose comparison of same AI (fadrozole) \\
\hline
\end{tabular}


(Continued)

Wang $2003 \quad$ Non-English paper.

Characteristics of ongoing studies [ordered by study ID]

ECOG E4101

\begin{tabular}{l|l}
\hline Trial name or title & ECOG E4101 \\
\hline Methods & \\
\hline Participants & $\begin{array}{l}\text { Target accrual }=148 \text { postmenopausal women with HR+ metastatic breast cancer previously treated with up } \\
\text { to two chemotherapy regimens and/or one prior endocrine therapy }\end{array}$ \\
\hline Interventions & faslodex + iressa v arimidex + iressa \\
\hline Outcomes & \\
\hline Starting date & Dr RW Carlson or AstroZeneca \\
\hline Contact information & currently recruiting in the USA \\
\hline Notes &
\end{tabular}

Efect

Trial name or title Efect

Phase III

Methods

Participants

Target accrual $=660 \mathrm{HR}+$ women with advanced disease who have previously received a non-steroidal AI therapy

Interventions faslodex $\mathrm{v}$ exemestane

Outcomes

Starting date

Contact information AstraZeneca

Notes currently recruiting in North America, Europe, South Africa, South America, Russia and Israel 


\section{ICR-CTSU Sofea}

Trial name or title $\quad$ Sofea
Phase III

Phase III

Methods

\begin{tabular}{ll}
\hline Participants & Target accrual $=750$ women with metastatic disease who have failed after non-steroidal AI \\
\hline Interventions & faslodes v faslodex + anastrozole vs exemestane \\
\hline Outcomes & March 2004 \\
\hline Starting date & Dr SRD Johnston, Royal Marsden Hospital email: sofea-icrctsu@icr.ac.uk \\
\hline Contact information & Open to recruitment in UK \\
\hline Notes & D
\end{tabular}

Paridaens 2003

\begin{tabular}{l|l}
\hline Trial name or title & Phase III EORTC-10951 \\
\hline Methods & \\
\hline Participants & Postmenopausal women with metastatic and progressive disease or locally recurrent and inoperable \\
\hline Interventions & exemestane v tamoxifen \\
\hline Outcomes & \\
\hline Starting date & robert.paridaens@uz.kuleven.ac.be \\
\hline Contact information & phase II to phase III study \\
\hline Notes &
\end{tabular}

HR+ HER positive 
DATA ANDANALYSES

\section{Comparison 1. AI versus non-AI}

\begin{tabular}{|c|c|c|c|c|}
\hline Outcome or subgroup title & $\begin{array}{l}\text { No. of } \\
\text { studies }\end{array}$ & $\begin{array}{c}\text { No. of } \\
\text { participants }\end{array}$ & Statistical method & Effect size \\
\hline $\begin{array}{l}1 \text { Overall survival (reported or } \\
\text { calculated) }\end{array}$ & 12 & & HR (Fixed, 95\% CI) & $0.89[0.82,0.96]$ \\
\hline $\begin{array}{l}1.1 \text { aminoglutethimide (any } \\
\text { dose) }\end{array}$ & 3 & & HR (Fixed, 95\% CI) & $0.88[0.72,1.08]$ \\
\hline 1.2 anastrozole $1 \mathrm{mg}$ & 3 & & HR (Fixed, 95\% CI) & $0.90[0.79,1.03]$ \\
\hline 1.3 exemestane $25 \mathrm{mg}$ & 1 & & HR (Fixed, 95\% CI) & $0.85[0.72,0.99]$ \\
\hline 1.4 fadrozole $2 \mathrm{mg}$ & 2 & & HR (Fixed, 95\% CI) & $1.04[0.77,1.40]$ \\
\hline 1.5 letrozole $2.5 \mathrm{mg}$ & 2 & & HR (Fixed, 95\% CI) & $0.88[0.73,1.05]$ \\
\hline 1.6 vorozole $2.5 \mathrm{mg}$ & 1 & & HR (Fixed, 95\% CI) & $1.10[0.49,2.47]$ \\
\hline $\begin{array}{l}2 \text { Progression-free survival } \\
\text { (reported or calculated) }\end{array}$ & 10 & & HR (Random, 95\% CI) & $0.97[0.83,1.14]$ \\
\hline $\begin{array}{l}2.1 \text { aminoglutethimide (any } \\
\text { dose) }\end{array}$ & 2 & & HR (Random, 95\% CI) & $1.07[0.73,1.55]$ \\
\hline 2.2 formestane $250 \mathrm{mg}$ & 1 & & HR (Random, 95\% CI) & $0.93[0.68,1.28]$ \\
\hline 2.3 anastrozole $1 \mathrm{mg}$ & 2 & & HR (Random, 95\% CI) & $1.05[0.65,1.70]$ \\
\hline 2.4 exemestane $25 \mathrm{mg}$ & 1 & & HR (Random, 95\% CI) & $0.82[0.70,0.97]$ \\
\hline 2.5 letrozole $2.5 \mathrm{mg}$ & 3 & & HR (Random, 95\% CI) & $0.87[0.68,1.11]$ \\
\hline 2.6 vorozole $2.5 \mathrm{mg}$ & 1 & & HR (Random, 95\% CI) & $1.27[1.04,1.56]$ \\
\hline 3 Clinical benefit (assessable) & 22 & 7594 & Odds Ratio (M-H, Random, 95\% CI) & $0.88[0.76,1.02]$ \\
\hline $\begin{array}{l}3.1 \text { aminoglutethimide (any } \\
\text { dose) }\end{array}$ & 5 & 637 & Odds Ratio (M-H, Random, 95\% CI) & $0.89[0.65,1.23]$ \\
\hline 3.2 formestane $250 \mathrm{mg}$ & 2 & 521 & Odds Ratio (M-H, Random, 95\% CI) & $1.05[0.59,1.86]$ \\
\hline 3.3 anastrozole $1 \mathrm{mg}$ & 4 & 2626 & Odds Ratio (M-H, Random, 95\% CI) & $0.74[0.48,1.12]$ \\
\hline 3.4 exemestane $25 \mathrm{mg}$ & 2 & 816 & Odds Ratio (M-H, Random, 95\% CI) & $0.71[0.39,1.31]$ \\
\hline 3.5 fadrozole $2 \mathrm{mg}$ & 4 & 982 & Odds Ratio (M-H, Random, 95\% CI) & $1.05[0.80,1.38]$ \\
\hline 3.6 letrozole $2.5 \mathrm{mg}$ & 4 & 1637 & Odds Ratio (M-H, Random, 95\% CI) & $0.77[0.60,1.00]$ \\
\hline 3.7 vorozole $2.5 \mathrm{mg}$ & 1 & 375 & Odds Ratio (M-H, Random, 95\% CI) & $1.35[0.88,2.07]$ \\
\hline 4 Objective response (assessable) & 25 & 7919 & Odds Ratio (M-H, Random, 95\% CI) & $0.88[0.75,1.02]$ \\
\hline $\begin{array}{l}4.1 \text { aminoglutethimide (any } \\
\text { dose) }\end{array}$ & 7 & 888 & Odds Ratio (M-H, Random, 95\% CI) & $0.92[0.62,1.38]$ \\
\hline 4.2 formestane $250 \mathrm{mg}$ & 2 & 521 & Odds Ratio (M-H, Random, 95\% CI) & $1.16[0.79,1.70]$ \\
\hline 4.3 anastrozole $1 \mathrm{mg}$ & 4 & 2626 & Odds Ratio (M-H, Random, 95\% CI) & $0.95[0.77,1.17]$ \\
\hline 4.4 exemestane $25 \mathrm{mg}$ & 2 & 816 & Odds Ratio (M-H, Random, 95\% CI) & $0.49[0.17,1.48]$ \\
\hline 4.5 fadrozole $2 \mathrm{mg}$ & 5 & 1056 & Odds Ratio (M-H, Random, 95\% CI) & $1.18[0.85,1.65]$ \\
\hline 4.6 letrozole $2.5 \mathrm{mg}$ & 4 & 1637 & Odds Ratio (M-H, Random, 95\% CI) & $0.65[0.51,0.82]$ \\
\hline 4.7 vorozole $2.5 \mathrm{mg}$ & 1 & 375 & Odds Ratio (M-H, Random, 95\% CI) & $0.70[0.34,1.42]$ \\
\hline 5 Clinical benefit (randomised) & 22 & 8008 & Odds Ratio (M-H, Random, 95\% CI) & $0.89[0.78,1.02]$ \\
\hline $\begin{array}{l}5.1 \text { aminoglutethimide (any } \\
\text { dose) }\end{array}$ & 5 & 671 & Odds Ratio (M-H, Random, 95\% CI) & $0.92[0.67,1.25]$ \\
\hline 5.2 formestane $250 \mathrm{mg}$ & 2 & 586 & Odds Ratio (M-H, Random, 95\% CI) & $1.00[0.58,1.70]$ \\
\hline 5.3 anastrozole $1 \mathrm{mg}$ & 4 & 2626 & Odds Ratio (M-H, Random, 95\% CI) & $0.74[0.48,1.12]$ \\
\hline 5.4 exemestane $25 \mathrm{mg}$ & 2 & 891 & Odds Ratio (M-H, Random, 95\% CI) & $0.78[0.53,1.17]$ \\
\hline 5.5 fadrozole $2 \mathrm{mg}$ & 4 & 1000 & Odds Ratio (M-H, Random, 95\% CI) & $1.08[0.82,1.41]$ \\
\hline
\end{tabular}

Aromatase inhibitors for treatment of advanced breast cancer in postmenopausal women (Review) 


\begin{tabular}{|c|c|c|c|c|}
\hline 5.6 letrozole $2.5 \mathrm{mg}$ & 4 & 1782 & Odds Ratio (M-H, Random, 95\% CI) & $0.77[0.61,0.96]$ \\
\hline 5.7 vorozole $2.5 \mathrm{mg}$ & 1 & 452 & Odds Ratio (M-H, Random, 95\% CI) & $1.25[0.83,1.88]$ \\
\hline 6 Objective response (randomised) & 25 & 8458 & Odds Ratio (M-H, Random, 95\% CI) & $0.90[0.77,1.06]$ \\
\hline $\begin{array}{l}6.1 \text { aminoglutethimide (any } \\
\text { dose) }\end{array}$ & 7 & 1041 & Odds Ratio (M-H, Random, 95\% CI) & $1.05[0.68,1.64]$ \\
\hline 6.2 formestane $250 \mathrm{mg}$ & 2 & 586 & Odds Ratio (M-H, Random, 95\% CI) & $1.13[0.78,1.65]$ \\
\hline 6.3 anastrozole $1 \mathrm{mg}$ & 4 & 2626 & Odds Ratio (M-H, Random, 95\% CI) & $0.95[0.77,1.17]$ \\
\hline 6.4 exemestane $25 \mathrm{mg}$ & 2 & 891 & Odds Ratio (M-H, Random, 95\% CI) & $0.52[0.20,1.37]$ \\
\hline 6.5 fadrozole $2 \mathrm{mg}$ & 5 & 1080 & Odds Ratio (M-H, Random, 95\% CI) & $1.21[0.87,1.69]$ \\
\hline 6.6 letrozole $2.5 \mathrm{mg}$ & 4 & 1782 & Odds Ratio (M-H, Random, 95\% CI) & $0.65[0.52,0.82]$ \\
\hline 6.7 vorozole $2.5 \mathrm{mg}$ & 1 & 452 & Odds Ratio (M-H, Random, 95\% CI) & $0.67[0.33,1.37]$ \\
\hline
\end{tabular}

Comparison 2. AI versus non-AI: Toxicity

\begin{tabular}{|c|c|c|c|c|}
\hline Outcome or subgroup title & $\begin{array}{l}\text { No. of } \\
\text { studies }\end{array}$ & $\begin{array}{c}\text { No. of } \\
\text { participants }\end{array}$ & Statistical method & Effect size \\
\hline 1 hot flushes & 18 & & Odds Ratio (M-H, Fixed, 95\% CI) & Subtotals only \\
\hline 1.1 AI versus tamoxifen & 7 & 2616 & Odds Ratio (M-H, Fixed, 95\% CI) & $1.07[0.88,1.29]$ \\
\hline 1.2 AI versus megestrol acetate & 9 & 3379 & Odds Ratio (M-H, Fixed, 95\% CI) & $1.77[1.42,2.20]$ \\
\hline 1.3 AI versus fulvestrant & 1 & 846 & Odds Ratio (M-H, Fixed, 95\% CI) & $0.97[0.70,1.35]$ \\
\hline $\begin{array}{l}1.4 \text { AI versus } \\
\text { medroxyprogesterone acetate }\end{array}$ & 1 & 218 & Odds Ratio (M-H, Fixed, 95\% CI) & $0.20[0.06,0.73]$ \\
\hline 2 nausea & 15 & & Odds Ratio (M-H, Random, 95\% CI) & Subtotals only \\
\hline 2.1 AI versus tamoxifen & 6 & 2548 & Odds Ratio (M-H, Random, 95\% CI) & $1.29[0.78,2.13]$ \\
\hline $2.2 \mathrm{AI}$ versus megestrol acetate & 8 & 3208 & Odds Ratio (M-H, Random, 95\% CI) & $1.84[1.37,2.47]$ \\
\hline 2.3 AI versus fulvestrant & 1 & 846 & Odds Ratio (M-H, Random, 95\% CI) & $0.96[0.71,1.31]$ \\
\hline 3 vomiting & 8 & & Odds Ratio (M-H, Fixed, 95\% CI) & Subtotals only \\
\hline 3.1 AI versus tamoxifen & 2 & 1239 & Odds Ratio (M-H, Fixed, 95\% CI) & $1.23[0.79,1.90]$ \\
\hline 3.2 AI versus megestrol acetate & 5 & 2319 & Odds Ratio (M-H, Fixed, 95\% CI) & $2.03[1.42,2.90]$ \\
\hline 3.3 AI versus fulvestrant & 1 & 846 & Odds Ratio (M-H, Fixed, 95\% CI) & $0.90[0.60,1.35]$ \\
\hline 4 diarrhoea & 9 & & Odds Ratio (M-H, Fixed, 95\% CI) & Subtotals only \\
\hline 4.1 AI versus tamoxifen & 3 & 2149 & Odds Ratio (M-H, Fixed, 95\% CI) & $1.64[1.06,2.55]$ \\
\hline 4.2 AI versus megestrol acetate & 5 & 1961 & Odds Ratio (M-H, Fixed, 95\% CI) & $1.48[1.02,2.13]$ \\
\hline 4.3 AI versus fulvestrant & 1 & 397 & Odds Ratio (M-H, Fixed, 95\% CI) & $1.41[0.84,2.35]$ \\
\hline 5 rash & 12 & & Odds Ratio (M-H, Random, 95\% CI) & Subtotals only \\
\hline 5.1 AI versus tamoxifen & 4 & 711 & Odds Ratio (M-H, Random, 95\% CI) & $33.61[4.71,239.97]$ \\
\hline 5.2 AI versus megestrol acetate & 6 & 2496 & Odds Ratio (M-H, Random, 95\% CI) & $1.83[0.77,4.39]$ \\
\hline $\begin{array}{l}\text { 5.3 AI versus } \\
\text { medroxyprogesterone acetate }\end{array}$ & 1 & 218 & Odds Ratio (M-H, Random, 95\% CI) & $\begin{array}{l}111.71[6.75,1849 . \\
91]\end{array}$ \\
\hline 5.4 AI versus fulvestrant & 1 & 397 & Odds Ratio (M-H, Random, 95\% CI) & $1.39[0.77,2.50]$ \\
\hline 6 vaginal bleeding & 4 & & Odds Ratio (M-H, Fixed, 95\% CI) & Subtotals only \\
\hline 6.1 AI versus tamoxifen & 1 & 1017 & Odds Ratio (M-H, Fixed, 95\% CI) & $0.45[0.16,1.32]$ \\
\hline 6.2 AI versus megestrol acetate & 2 & 915 & Odds Ratio (M-H, Fixed, 95\% CI) & $0.29[0.13,0.65]$ \\
\hline $\begin{array}{l}6.3 \text { AI versus } \\
\text { medroxyprogesterone acetate }\end{array}$ & 1 & 218 & Odds Ratio (M-H, Fixed, 95\% CI) & $0.10[0.01,0.77]$ \\
\hline 7 thromboembolic & 6 & & Odds Ratio (M-H, Fixed, 95\% CI) & Subtotals only \\
\hline 7.1 AI versus tamoxifen & 2 & 1228 & Odds Ratio (M-H, Fixed, 95\% CI) & $0.48[0.27,0.85]$ \\
\hline 7.2 AI versus megestrol acetate & 3 & 863 & Odds Ratio (M-H, Fixed, 95\% CI) & $0.54[0.26,1.10]$ \\
\hline 7.3 AI versus fulvestrant & 1 & 846 & Odds Ratio (M-H, Fixed, 95\% CI) & $1.14[0.56,2.31]$ \\
\hline
\end{tabular}

Aromatase inhibitors for treatment of advanced breast cancer in postmenopausal women (Review) 
8 arthralgia

Odds Ratio (M-H, Fixed, 95\% CI)

Subtotals only

8.1 AI versus tamoxifen $\quad 2 \quad 1031$

Odds Ratio (M-H, Fixed, 95\% CI)

$1.14[0.81,1.60]$

8.2 AI versus megestrol acetate

4

1439

Odds Ratio (M-H, Fixed, 95\% CI)

$1.40[0.98,2.00]$

\section{Comparison 3. Current AIs versus non-AI}

\begin{tabular}{|c|c|c|c|c|}
\hline Outcome or subgroup title & $\begin{array}{l}\text { No. of } \\
\text { studies }\end{array}$ & $\begin{array}{c}\text { No. of } \\
\text { participants }\end{array}$ & Statistical method & Effect size \\
\hline $\begin{array}{l}1 \text { Overall survival (reported or } \\
\text { calculated) }\end{array}$ & 6 & & HR (Fixed, 95\% CI) & $0.88[0.80,0.96]$ \\
\hline 1.1 anastrozole $1 \mathrm{mg}$ & 3 & & HR (Fixed, 95\% CI) & $0.90[0.79,1.03]$ \\
\hline 1.2 exemestane $25 \mathrm{mg}$ & 1 & & HR (Fixed, 95\% CI) & $0.85[0.72,0.99]$ \\
\hline 1.3 letrozole $2.5 \mathrm{mg}$ & 2 & & HR (Fixed, 95\% CI) & $0.88[0.73,1.05]$ \\
\hline $\begin{array}{r}2 \text { Progression-free survival } \\
\text { (reported or calculated) }\end{array}$ & 6 & & HR (Random, 95\% CI) & $0.92[0.75,1.13]$ \\
\hline 2.1 anastrozole $1 \mathrm{mg}$ & 2 & & HR (Random, 95\% CI) & $1.05[0.65,1.70]$ \\
\hline 2.2 exemestane $25 \mathrm{mg}$ & 1 & & HR (Random, 95\% CI) & $0.82[0.70,0.97]$ \\
\hline 2.3 letrozole $2.5 \mathrm{mg}$ & 3 & & HR (Random, 95\% CI) & $0.87[0.68,1.11]$ \\
\hline 3 Clinical benefit (assessable) & 10 & 5079 & Odds Ratio (M-H, Random, 95\% CI) & $0.78[0.63,0.96]$ \\
\hline 3.1 anastrozole $1 \mathrm{mg}$ & 4 & 2626 & Odds Ratio (M-H, Random, 95\% CI) & $0.74[0.48,1.12]$ \\
\hline 3.2 exemestane $25 \mathrm{mg}$ & 2 & 816 & Odds Ratio (M-H, Random, 95\% CI) & $0.71[0.39,1.31]$ \\
\hline 3.3 letrozole $2.5 \mathrm{mg}$ & 4 & 1637 & Odds Ratio (M-H, Random, 95\% CI) & $0.77[0.60,1.00]$ \\
\hline 4 Objective response (assessable) & 10 & 5079 & Odds Ratio (M-H, Random, 95\% CI) & $0.77[0.62,0.96]$ \\
\hline 4.1 anastrozole $1 \mathrm{mg}$ & 4 & 2626 & Odds Ratio (M-H, Random, 95\% CI) & $0.95[0.77,1.17]$ \\
\hline 4.2 exemestane $25 \mathrm{mg}$ & 2 & 816 & Odds Ratio (M-H, Random, 95\% CI) & $0.49[0.17,1.48]$ \\
\hline 4.3 letrozole $2.5 \mathrm{mg}$ & 4 & 1637 & Odds Ratio (M-H, Random, 95\% CI) & $0.65[0.51,0.82]$ \\
\hline 5 Clinical benefit (randomised) & 10 & 5299 & Odds Ratio (M-H, Random, 95\% CI) & $0.79[0.64,0.96]$ \\
\hline 5.1 anastrozole $1 \mathrm{mg}$ & 4 & 2626 & Odds Ratio (M-H, Random, 95\% CI) & $0.74[0.48,1.12]$ \\
\hline 5.2 exemestane $25 \mathrm{mg}$ & 2 & 891 & Odds Ratio (M-H, Random, 95\% CI) & $0.78[0.53,1.17]$ \\
\hline 5.3 letrozole $2.5 \mathrm{mg}$ & 4 & 1782 & Odds Ratio (M-H, Random, 95\% CI) & $0.77[0.61,0.96]$ \\
\hline 6 Objective response (randomised) & 10 & 5299 & Odds Ratio (M-H, Random, 95\% CI) & $0.78[0.64,0.95]$ \\
\hline 6.1 anastrozole $1 \mathrm{mg}$ & 4 & 2626 & Odds Ratio (M-H, Random, 95\% CI) & $0.95[0.77,1.17]$ \\
\hline 6.2 exemestane $25 \mathrm{mg}$ & 2 & 891 & Odds Ratio (M-H, Random, 95\% CI) & $0.52[0.20,1.37]$ \\
\hline 6.3 letrozole $2.5 \mathrm{mg}$ & 4 & 1782 & Odds Ratio (M-H, Random, 95\% CI) & $0.65[0.52,0.82]$ \\
\hline
\end{tabular}

Comparison 4. Current AIs versus non-AI: Toxicity

\begin{tabular}{lcccc} 
Outcome or subgroup title & $\begin{array}{c}\text { No. of } \\
\text { studies }\end{array}$ & $\begin{array}{c}\text { No. of } \\
\text { participants }\end{array}$ & Statistical method & Effect size \\
\hline 1 hot flushes & 8 & & Odds Ratio (M-H, Fixed, 95\% CI) & Subtotals only \\
$\quad$ 1.1 AI versus tamoxifen & 3 & 2048 & Odds Ratio (M-H, Fixed, 95\% CI) & $1.13[0.91,1.39]$ \\
$\begin{array}{l}1.2 \text { AI versus megestrol acetate } \\
\text { 1.3 AI versus fulvestrant }\end{array}$ & 4 & 2036 & Odds Ratio (M-H, Fixed, 95\% CI) & $1.69[1.24,2.30]$ \\
2 nausea & 8 & 846 & Odds Ratio (M-H, Fixed, 95\% CI) & $0.97[0.70,1.35]$ \\
$\quad 2.1$ AI versus tamoxifen & 3 & 2048 & Odds Ratio (M-H, Fixed, 95\% CI) & Subtotals only \\
\end{tabular}

Aromatase inhibitors for treatment of advanced breast cancer in postmenopausal women (Review)

Copyright @ 2009 The Cochrane Collaboration. Published by John Wiley \& Sons, Ltd. 


2.2 AI versus megestrol acetate
$2.3 \mathrm{AI}$ versus fulvestrant
3 vomiting
3.1 AI versus tamoxifen
3.2 AI versus megestrol acetate
$3.3 \mathrm{AI}$ versus fulvestrant
4 diarrhoea
$4.1 \mathrm{AI}$ versus tamoxifen
$4.2 \mathrm{AI}$ versus megestrol acetate
$4.3 \mathrm{AI}$ versus fulvestrant
5 rash
$5.1 \mathrm{AI}$ versus megestrol acetate
$5.2 \mathrm{AI}$ versus fulvestrant
6 vaginal bleeding
$6.1 \mathrm{AI}$ versus tamoxifen
$6.2 \mathrm{AI}$ versus megestrol acetate
7 thromboembolic
$7.1 \mathrm{AI}$ versus tamoxifen
$7.2 \mathrm{AI}$ versus megestrol acetate
$7.3 \mathrm{AI}$ versus fulvestrant
8 arthralgia
$8.1 \mathrm{AI}$ versus tamoxifen
$8.2 \mathrm{AI}$ versus megestrol acetate

$\begin{array}{cc}4 & 2036 \\ 1 & 846 \\ 5 & \\ 1 & 1017 \\ 3 & 1636 \\ 1 & 846 \\ 6 & \\ 2 & 1927 \\ 3 & 1278 \\ 1 & 397 \\ 4 & \\ 3 & 1636 \\ 1 & 397 \\ 3 & \\ 1 & 1017 \\ 2 & 915 \\ 3 & \\ 1 & 1017 \\ 1 & 515 \\ 1 & 846 \\ 3 & \\ 2 & 1031 \\ 1 & 363\end{array}$

Odds Ratio (M-H, Fixed, 95\% CI)

$1.45[1.09,1.95]$ Odds Ratio (M-H, Fixed, 95\% CI)

$0.96[0.71,1.31]$

Subtotals only Odds Ratio (M-H, Fixed, 95\% CI)

$1.07[0.67,1.72]$

$1.77[1.11,2.83]$

Odds Ratio (M-H, Fixed, 95\% CI)

$0.90[0.60,1.35]$

Subtotals only Odds Ratio (M-H, Fixed, 95\% CI)

$1.49[0.95,2.35]$ Odds Ratio (M-H, Fixed, 95\% CI)

$2.40[1.34,4.29]$

Odds Ratio (M-H, Fixed, 95\% CI)

$1.41[0.84,2.35]$

Odds Ratio (M-H, Fixed, 95\% CI)

Subtotals only

Odds Ratio (M-H, Random, 95\% CI)

$1.63[0.47,5.70]$

Odds Ratio (M-H, Random, 95\% CI)

$1.39[0.77,2.50]$

Odds Ratio (M-H, Random, 95\% CI)

Subtotals only Odds Ratio (M-H, Fixed, 95\% CI)

$0.45[0.16,1.32]$

Odds Ratio (M-H, Fixed, 95\% CI)

$0.29[0.13,0.65]$

Odds Ratio (M-H, Fixed, 95\% CI)

Subtotals only

$0.53[0.30,0.96]$

$0.71[0.30,1.73]$

$1.14[0.56,2.31]$

Subtotals only

$1.14[0.81,1.60]$

$1.77[0.89,3.51]$

\section{Comparison 5. AI versus different AI}

\begin{tabular}{|c|c|c|c|c|}
\hline Outcome or subgroup title & $\begin{array}{l}\text { No. of } \\
\text { studies }\end{array}$ & $\begin{array}{c}\text { No. of } \\
\text { participants }\end{array}$ & Statistical method & Effect size \\
\hline 1 Overall survival (reported) & 1 & & HR (Fixed, 95\% CI) & Subtotals only \\
\hline 1.1 letrozole & 1 & & HR (Fixed, 95\% CI) & $0.64[0.49,0.84]$ \\
\hline $\begin{array}{l}2 \text { Progession-free survival } \\
\text { (reported or calculated) }\end{array}$ & 1 & & HR (Fixed, 95\% CI) & Subtotals only \\
\hline 2.1 letrozole & 1 & & HR (Fixed, 95\% CI) & $0.72[0.57,0.91]$ \\
\hline 3 Clinical benefit (assessable) & 4 & & Odds Ratio (M-H, Fixed, 95\% CI) & Subtotals only \\
\hline 3.1 letrozole & 3 & 1092 & Odds Ratio (M-H, Fixed, 95\% CI) & $0.72[0.56,0.93]$ \\
\hline 3.2 anastrozole & 2 & 663 & Odds Ratio (M-H, Fixed, 95\% CI) & $1.29[0.92,1.79]$ \\
\hline 4 Objective response (assessable) & 4 & & Odds Ratio (M-H, Fixed, 95\% CI) & Subtotals only \\
\hline 4.1 letrozole & 3 & 1092 & Odds Ratio (M-H, Fixed, 95\% CI) & $0.53[0.39,0.73]$ \\
\hline 4.2 anastrozole & 2 & 663 & Odds Ratio (M-H, Fixed, 95\% CI) & $1.59[1.07,2.37]$ \\
\hline 5 Clinical benefit (randomised) & 4 & & Odds Ratio (M-H, Fixed, 95\% CI) & Subtotals only \\
\hline 5.1 letrozole & 3 & 1233 & Odds Ratio (M-H, Fixed, 95\% CI) & $0.74[0.57,0.94]$ \\
\hline 5.2 anastrozole & 2 & 773 & Odds Ratio (M-H, Fixed, 95\% CI) & $1.25[0.90,1.72]$ \\
\hline 6 Objective response (randomised) & 4 & & Odds Ratio (M-H, Fixed, 95\% CI) & Subtotals only \\
\hline 6.1 letrozole & 3 & 1233 & Odds Ratio (M-H, Fixed, 95\% CI) & $0.54[0.40,0.74]$ \\
\hline 6.2 anastrozole & 2 & 782 & Odds Ratio (M-H, Fixed, 95\% CI) & $1.50[1.01,2.23]$ \\
\hline
\end{tabular}

Aromatase inhibitors for treatment of advanced breast cancer in postmenopausal women (Review) 


\begin{tabular}{|c|c|c|c|c|}
\hline Outcome or subgroup title & $\begin{array}{l}\text { No. of } \\
\text { studies }\end{array}$ & $\begin{array}{c}\text { No. of } \\
\text { participants }\end{array}$ & Statistical method & Effect size \\
\hline $\begin{array}{l}1 \text { Overall survival (reported or } \\
\text { calculated) }\end{array}$ & 2 & & HR (Fixed, 95\% CI) & $0.96[0.81,1.13]$ \\
\hline $\begin{array}{l}1.1 \text { anastrozole as first-line } \\
\text { therapy }\end{array}$ & 1 & & HR (Fixed, 95\% CI) & $0.97[0.81,1.16]$ \\
\hline $\begin{array}{l}1.2 \text { fadrozole as first-line } \\
\text { therapy }\end{array}$ & 1 & & HR (Fixed, 95\% CI) & $0.91[0.63,1.32]$ \\
\hline $\begin{array}{l}2 \text { Progression-free survival } \\
\text { (reported or calculated) }\end{array}$ & 3 & & HR (Fixed, 95\% CI) & $0.78[0.70,0.86]$ \\
\hline $\begin{array}{l}2.1 \text { formestane as first-line } \\
\text { therapy }\end{array}$ & 1 & & HR (Fixed, 95\% CI) & $0.93[0.68,1.28]$ \\
\hline $\begin{array}{l}2.2 \text { anastrozole as first-line } \\
\text { therapy }\end{array}$ & 1 & & HR (Fixed, 95\% CI) & $0.82[0.71,0.95]$ \\
\hline $\begin{array}{l}2.3 \text { letrozole as first-line } \\
\text { therapy }\end{array}$ & 1 & & HR (Fixed, 95\% CI) & $0.70[0.60,0.82]$ \\
\hline 3 Clinical benefit (assessable) & 8 & 3036 & Odds Ratio (M-H, Random, 95\% CI) & $0.70[0.51,0.97]$ \\
\hline $\begin{array}{l}3.1 \text { aminoglutethimide (any } \\
\text { dose) }\end{array}$ & 2 & 263 & Odds Ratio (M-H, Random, 95\% CI) & $0.67[0.39,1.13]$ \\
\hline 3.2 formestane $250 \mathrm{mg}$ & 1 & 348 & Odds Ratio (M-H, Random, 95\% CI) & $1.36[0.87,2.13]$ \\
\hline 3.3 anastrozole $1 \mathrm{mg}$ & 2 & 1259 & Odds Ratio (M-H, Random, 95\% CI) & $0.48[0.16,1.44]$ \\
\hline 3.4 exemestane $25 \mathrm{mg}$ & 1 & 113 & Odds Ratio (M-H, Random, 95\% CI) & $0.47[0.22,0.99]$ \\
\hline 3.5 fadrozole $2 \mathrm{mg}$ & 1 & 209 & Odds Ratio (M-H, Random, 95\% CI) & $1.09[0.58,2.06]$ \\
\hline 3.6 letrozole $2.5 \mathrm{mg}$ & 1 & 844 & Odds Ratio (M-H, Random, 95\% CI) & $0.63[0.48,0.82]$ \\
\hline 4 Objective response (assessable) & 10 & 3287 & Odds Ratio (M-H, Random, 95\% CI) & $0.81[0.62,1.06]$ \\
\hline $\begin{array}{l}4.1 \text { aminoglutethimide (any } \\
\text { dose) }\end{array}$ & 3 & 440 & Odds Ratio (M-H, Random, 95\% CI) & $0.90[0.50,1.61]$ \\
\hline 4.2 formestane $250 \mathrm{mg}$ & 1 & 348 & Odds Ratio (M-H, Random, 95\% CI) & $1.20[0.77,1.87]$ \\
\hline 4.3 anastrozole $1 \mathrm{mg}$ & 2 & 1259 & Odds Ratio (M-H, Random, 95\% CI) & $0.85[0.65,1.11]$ \\
\hline 4.4 exemestane $25 \mathrm{mg}$ & 1 & 113 & Odds Ratio (M-H, Random, 95\% CI) & $0.26[0.11,0.62]$ \\
\hline 4.5 fadrozole $2 \mathrm{mg}$ & 2 & 283 & Odds Ratio (M-H, Random, 95\% CI) & $1.20[0.69,2.09]$ \\
\hline 4.6 letrozole $2.5 \mathrm{mg}$ & 1 & 844 & Odds Ratio (M-H, Random, 95\% CI) & $0.58[0.42,0.78]$ \\
\hline 5 Clinical benefit (randomised) & 8 & 3210 & Odds Ratio (M-H, Random, 95\% CI) & $0.75[0.55,1.02]$ \\
\hline $\begin{array}{l}5.1 \text { aminoglutethimide (any } \\
\text { dose) }\end{array}$ & 2 & 292 & Odds Ratio (M-H, Random, 95\% CI) & $0.89[0.38,2.08]$ \\
\hline 5.2 formestane $250 \mathrm{mg}$ & 1 & 409 & Odds Ratio (M-H, Random, 95\% CI) & $1.25[0.85,1.86]$ \\
\hline 5.3 anastrozole $1 \mathrm{mg}$ & 2 & 1259 & Odds Ratio (M-H, Random, 95\% CI) & $0.48[0.16,1.44]$ \\
\hline 5.4 exemestane $25 \mathrm{mg}$ & 1 & 122 & Odds Ratio (M-H, Random, 95\% CI) & $0.55[0.27,1.13]$ \\
\hline 5.5 fadrozole $2 \mathrm{mg}$ & 1 & 221 & Odds Ratio (M-H, Random, 95\% CI) & $1.23[0.69,2.21]$ \\
\hline 5.6 letrozole $2.5 \mathrm{mg}$ & 1 & 907 & Odds Ratio (M-H, Random, 95\% CI) & $0.65[0.50,0.84]$ \\
\hline 6 Objective response (randomised) & 10 & 3505 & Odds Ratio (M-H, Random, 95\% CI) & $0.85[0.65,1.11]$ \\
\hline $\begin{array}{l}6.1 \text { aminoglutethimide (any } \\
\text { dose) }\end{array}$ & 3 & 507 & Odds Ratio (M-H, Random, 95\% CI) & $1.01[0.52,1.96]$ \\
\hline 6.2 formestane $250 \mathrm{mg}$ & 1 & 409 & Odds Ratio (M-H, Random, 95\% CI) & $1.18[0.77,1.80]$ \\
\hline 6.3 anastrozole $1 \mathrm{mg}$ & 2 & 1259 & Odds Ratio (M-H, Random, 95\% CI) & $0.85[0.65,1.11]$ \\
\hline 6.4 exemestane $25 \mathrm{mg}$ & 1 & 122 & Odds Ratio (M-H, Random, 95\% CI) & $0.30[0.13,0.69]$ \\
\hline 6.5 fadrozole $2 \mathrm{mg}$ & 2 & 301 & Odds Ratio (M-H, Random, 95\% CI) & $1.28[0.76,2.15]$ \\
\hline 6.6 letrozole $2.5 \mathrm{mg}$ & 1 & 907 & Odds Ratio (M-H, Random, 95\% CI) & $0.59[0.43,0.79]$ \\
\hline
\end{tabular}




\begin{tabular}{|c|c|c|c|c|}
\hline Outcome or subgroup title & $\begin{array}{l}\text { No. of } \\
\text { studies }\end{array}$ & $\begin{array}{c}\text { No. of } \\
\text { participants }\end{array}$ & Statistical method & Effect size \\
\hline $\begin{array}{l}1 \text { Overall survival (reported or } \\
\text { calculated) }\end{array}$ & 2 & & HR (Fixed, 95\% CI) & $0.80[0.66,0.96]$ \\
\hline $\begin{array}{l}1.1 \text { anastrozole as second-line } \\
\text { therapy }\end{array}$ & 1 & & HR (Fixed, 95\% CI) & $0.78[0.61,1.00]$ \\
\hline $\begin{array}{l}1.2 \text { letrozole as second-line } \\
\text { therapy }\end{array}$ & 1 & & HR (Fixed, 95\% CI) & $0.82[0.63,1.07]$ \\
\hline $\begin{array}{l}2 \text { Progression-free survival } \\
\text { (reported or calculated) }\end{array}$ & 6 & & HR (Random, 95\% CI) & $1.08[0.89,1.31]$ \\
\hline $\begin{array}{l}2.1 \text { aminoglutethimide (any } \\
\text { dose) }\end{array}$ & 1 & & HR (Random, 95\% CI) & $1.25[0.91,1.72]$ \\
\hline $\begin{array}{l}2.2 \text { formestane } 250 \mathrm{mg} \\
\text { biweekly }\end{array}$ & 1 & & HR (Random, 95\% CI) & $0.93[0.68,1.28]$ \\
\hline 2.3 anastrozole $1 \mathrm{mg}$ & 1 & & HR (Random, 95\% CI) & $1.34[1.16,1.55]$ \\
\hline 2.4 exemestane $25 \mathrm{mg}$ & 1 & & HR (Random, 95\% CI) & $0.82[0.70,0.97]$ \\
\hline 2.5 letrozole $2.5 \mathrm{mg}$ & 1 & & HR (Random, 95\% CI) & $0.98[0.77,1.25]$ \\
\hline 2.6 vorozole $2.5 \mathrm{mg}$ & 1 & & HR (Random, 95\% CI) & $1.27[1.04,1.56]$ \\
\hline 3 Clinical benefit (assessable) & 11 & 3721 & Odds Ratio (M-H, Fixed, 95\% CI) & $1.00[0.87,1.14]$ \\
\hline $\begin{array}{l}3.1 \text { aminoglutethimide (any } \\
\text { dose) }\end{array}$ & 2 & 274 & Odds Ratio (M-H, Fixed, 95\% CI) & $1.19[0.74,1.92]$ \\
\hline $\begin{array}{l}3.2 \text { formestane } 250 \mathrm{mg} \\
\text { biweekly }\end{array}$ & 1 & 173 & Odds Ratio (M-H, Fixed, 95\% CI) & $0.75[0.41,1.39]$ \\
\hline 3.3 anastrozole $1 \mathrm{mg}$ & 2 & 1367 & Odds Ratio (M-H, Fixed, 95\% CI) & $1.04[0.84,1.29]$ \\
\hline 3.4 exemestane $25 \mathrm{mg}$ & 1 & 703 & Odds Ratio (M-H, Fixed, 95\% CI) & $0.90[0.66,1.22]$ \\
\hline 3.5 fadrozole $2 \mathrm{mg}$ & 3 & 773 & Odds Ratio (M-H, Fixed, 95\% CI) & $1.04[0.77,1.41]$ \\
\hline 3.6 letrozole $2.5 \mathrm{mg}$ & 2 & 431 & Odds Ratio (M-H, Fixed, 95\% CI) & $0.96[0.64,1.42]$ \\
\hline 4 Objective response (assessable) & 13 & 4170 & Odds Ratio (M-H, Fixed, 95\% CI) & $0.96[0.81,1.14]$ \\
\hline $\begin{array}{l}4.1 \text { aminoglutethimide (any } \\
\text { dose) }\end{array}$ & 3 & 348 & Odds Ratio (M-H, Fixed, 95\% CI) & $1.09[0.66,1.81]$ \\
\hline $\begin{array}{l}4.2 \text { formestane } 250 \mathrm{mg} \\
\text { biweekly }\end{array}$ & 1 & 173 & Odds Ratio (M-H, Fixed, 95\% CI) & $1.01[0.46,2.25]$ \\
\hline 4.3 anastrozole $1 \mathrm{mg}$ & 2 & 1367 & Odds Ratio (M-H, Fixed, 95\% CI) & $1.12[0.84,1.50]$ \\
\hline 4.4 exemestane $25 \mathrm{mg}$ & 1 & 703 & Odds Ratio (M-H, Fixed, 95\% CI) & $0.81[0.54,1.23]$ \\
\hline 4.5 fadrozole $2 \mathrm{mg}$ & 3 & 773 & Odds Ratio (M-H, Fixed, 95\% CI) & $1.17[0.76,1.80]$ \\
\hline 4.6 letrozole $2.5 \mathrm{mg}$ & 2 & 431 & Odds Ratio (M-H, Fixed, 95\% CI) & $0.65[0.41,1.04]$ \\
\hline 4.7 vorozole $2.5 \mathrm{mg}$ & 1 & 375 & Odds Ratio (M-H, Fixed, 95\% CI) & $0.70[0.34,1.42]$ \\
\hline 5 Clinical benefit (randomised) & 11 & 3846 & Odds Ratio (M-H, Fixed, 95\% CI) & $0.99[0.86,1.12]$ \\
\hline $\begin{array}{l}5.1 \text { aminoglutethimide (any } \\
\text { dose) }\end{array}$ & 2 & 279 & Odds Ratio (M-H, Fixed, 95\% CI) & $1.16[0.72,1.86]$ \\
\hline $\begin{array}{l}5.2 \text { formestane } 250 \mathrm{mg} \\
\text { biweekly }\end{array}$ & 1 & 177 & Odds Ratio (M-H, Fixed, 95\% CI) & $0.72[0.40,1.31]$ \\
\hline 5.3 anastrozole $1 \mathrm{mg}$ & 2 & 1367 & Odds Ratio (M-H, Fixed, 95\% CI) & $1.04[0.84,1.29]$ \\
\hline 5.4 exemestane $25 \mathrm{mg}$ & 1 & 769 & Odds Ratio (M-H, Fixed, 95\% CI) & $0.88[0.66,1.19]$ \\
\hline 5.5 fadrozole $2 \mathrm{mg}$ & 3 & 779 & Odds Ratio (M-H, Fixed, 95\% CI) & $1.04[0.77,1.41]$ \\
\hline 5.6 letrozole $2.5 \mathrm{mg}$ & 2 & 475 & Odds Ratio (M-H, Fixed, 95\% CI) & $0.96[0.65,1.41]$ \\
\hline 6 Objective response (randomised) & 13 & 4453 & Odds Ratio (M-H, Fixed, 95\% CI) & $0.95[0.80,1.12]$ \\
\hline
\end{tabular}

